\title{
IํำPED
}

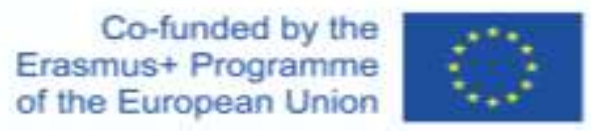

DOI $10.28925 / 2414-0325.2020$ spv1

Nataliia Morze,

Professor, Doctor of Pedagogy,

Corresponding Member of the National Academy of

Sciences of Ukraine,

Borys Grinchenko Kyiv University, Kyiv, Ukraine

n.morze@ kubg.edu.ua

ORCID: 0000-0003-3477-9254

\section{Svitlana Vasylenko}

Deputy for content and research Head of IT in

Education Laboratory

Borys Grinchenko Kyiv University, Kyiv, Ukraines.

vasylenko@kubg.edu.ua

ORCID: 0000-0002-5790-572X

\section{Морзе Наталія Вікторівна,}

професор, доктор педагогічних наук, членкореспондент НАПН України,

Київський університет імені Бориса Грінченка,

Київ, Україна

n.morze@kubg.edu.ua

ORCID: 0000-0003-3477-9254

\section{Василенко Світлана Василівна}

Заступник завідувача 3 питань змісту та дослідження НДЛ інформатизації освіти

Київський університет імені Бориса Грінченка, Київ, Україна

s.vasylenko@kubg.edu.ua

ORCID: 0000-0002-5790-572X

\section{REPORT 1}

\section{Work Package 1: EU and UA Pedagogical Higher Education profound analysis and study} in the Framework of the

Modernization of Pedagogical Higher Education by Innovative Teaching Instruments (MoPED) 586098-EPP-1-2017-1-UA-EPPKA2-CBHE-JP

\section{INNOVATIVE TEACHING AND BEST PRACTICES: UKRAINE UNIVERSITIES ІННОВАЦЙНЕ НАВЧАННЯ ТА НАЙКРАЩІ ПРАКТИКИ: УКРАЇНСЬКІ УНІВЕРСИТЕТИ}

\begin{abstract}
Анотація. Метою даного дослідження було виявлення найбільш вживаних, популярних інноваційних технологій, кращих педагогічних практик; порівняння 3 досвідом університетів СС та створення рекомендацій, що дадуть змогу українським партнерам у майбутньому готувати здобувачів вищої освіти конкуренто спроможних на ринку праці. Дане дослідження проведено задля реалізації однієї з цілей проєкту - ефективної співпраці між педагогічним сектором вищої освіти України та ЄС, викладачами шкіл та їх об'єднаннями. Перед українськими учасниками проєкту постали завдання: сформулювати розуміння необхідних аспектів для створення профілю компетентності студента в нових дисциплінах, побудувати профілі цифрової компетентності вчителя та викладача університету на основі обміну знаннями, отриманими від партнерів СС. В рамках виконання завдань проєкту було проведено аналіз рівня використовуваних освітніх програм та кращих педагогічних практик, питання важливості спільнот, обміну педагогічним досвідом між викладачами університету та у підрозділах університетів, технологічні особливості підтримки керівництва університету інноваційної діяльності викладачів, долучення студентів до наукової та проєктної діяльності, рівень використання технічних засобів викладачами українських університетів - партнерів проєкту, актуальні системи оцінювання та пріоритетні напрями формування навчальної культури.
\end{abstract}

Ключові слова: інноваційне навчання; інноваційні технології; здобувачі вищої освіти; профіль цифрової компетентності; навчальна культура.

The European Commission support for the production of this publication does not constitute an endorsement of the contents which reflects the views only of the authors, and the Commission cannot be held responsible for any use which may be made of the information contained therein. 
3MICT

Виконавче резюме .5

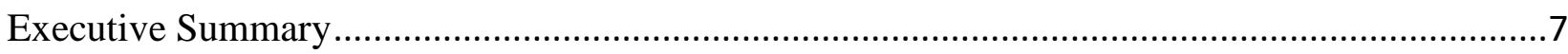

ВСТУП

І. ЗАГАЛЬНА АДМІНІСТРАТИВНА ІНФОРМАЦІЯ ПРО УНІВЕРСИТЕТ

Проєкти, що відносяться до інноваційного викладання та / або застосування технологій у навчанні / викладанні.

II. ОРГАНІЗАЦІЙНІ ПИТАННЯ

Правова база для використання інноваційних інструментів та технологій навчання на Державному рівні

Правова основа для проведення занять за дистанційною формою

Система контролю якості навчальних матеріалів, рівня задоволення студентів навчальними матеріалами, що підготовлені викладачами

Спеціальний підрозділ підтримки в університеті інноваційних методів та технології навчання . ....

Програми, що підтримують інноваційні методи та технології навчання.

Підтримка інтелектуальної власності в університетах

Впровадження інноваційних інструментів та технологій навчання .22

Репозиторії навчальних ресурсів

III ОПИС ПРОГРАМИ ТА НАВЧАЛЬНА ПРАКТИКА 24

Опис результатів навчання в освітніх програмах

Використання прикладів практичних досліджень та результатів наукових досліджень ..25

Форми інноваційних методів та технологій навчання у навчальних програмах................26

Підтримка кафедри при перегляді навчальних програм …...............................................27

Структура навчальної програми

Курси або навчальні модулі, інтегровані в навчальний план, під час яких обговорюється тема «Технології дистанційної освіти» 28

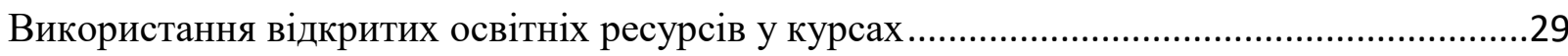

Освітні ресурси $з$ ліцензією Creative Commons …...........................................................30

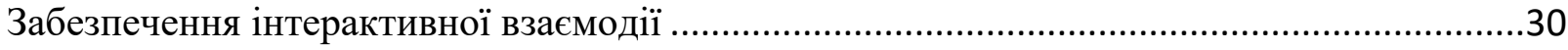

Навчальний курс для навчання інтегрованій освіті.....................................................31

Навчання студентів soft skills та рівень їх сформованості ..............................................31

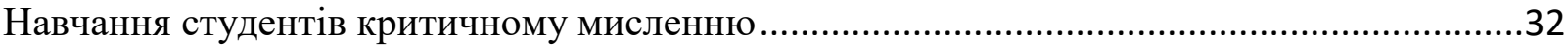




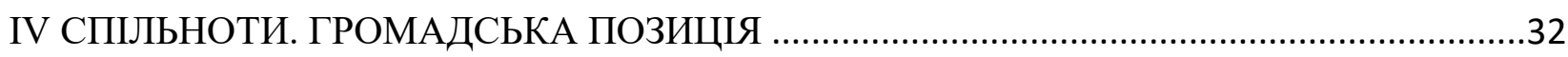

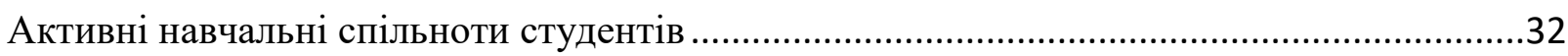

Обмін найкращими практиками серед викладачів ......................................................33

Різноманітність студентів та врахування їх в освітньому процесі ……............................34

Залучення студентів до науково-дослідних проєктів......................................................35

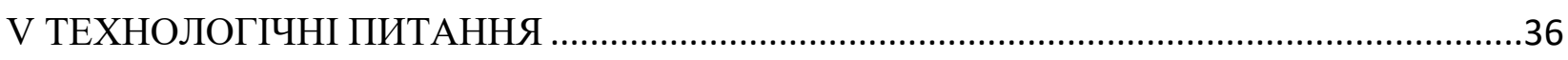

Впровадження інноваційних методів та освітніх технологій.........................................36

Підтримка адміністрації університету з питань розширення інфраструктури

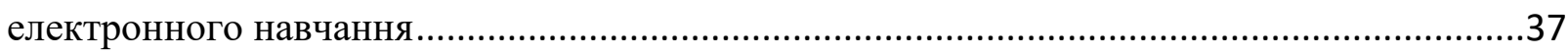

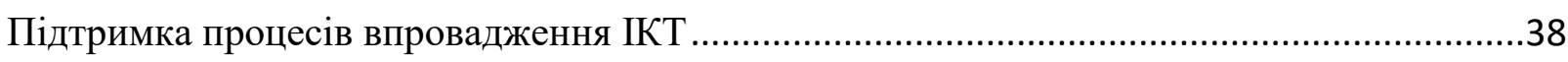

Використання онлайн-середовища для підтримки навчальних курсів .............................39

Основні інвестиції в цифрову інфраструктуру в останні кілька років ..............................39

Підтримка інформаційної безпеки ............................................................................. 40

Розвиток стартапів та екосистеми в Університеті ...........................................................40

Приклади трансформації освітнього процесу університету, які відбулися завдяки ефективному впровадженню ІКТ .............................................................................41

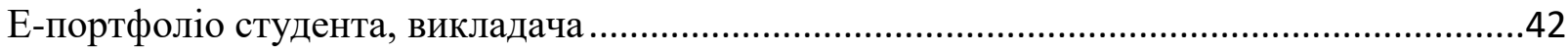

Електронний кабінет викладача ….........................................................................42

Використання електронного журналу та е-деканату....................................................43

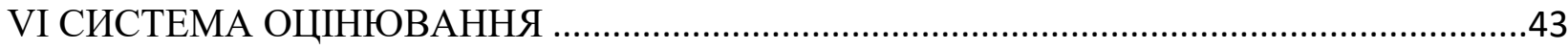

Методика забезпечення якості оцінювання програм з використанням інноваційних

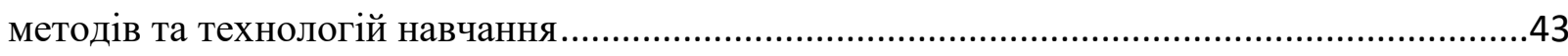

Оцінювання інноваційного змісту навчання та використання інноваційних методів та

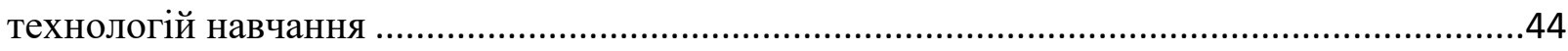

Контроль та оцінка програм, що включають інноваційні методи та технології навчання44 Рейтингова система для професорсько-викладацького складу ….....................................45

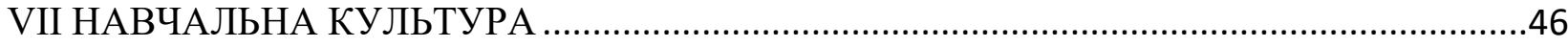

Стимулювання та підтримка співробітників у використанні електронного навчання та

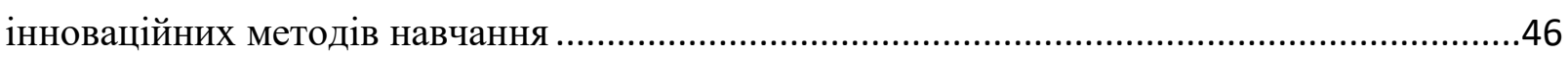

Оцінювання цифрових компетентностей викладачів .....................................................47

Оцінювання цифрових компетентностей студентів ....................................................48

Вирішення завдань персоналізації та адаптивного навчання ........................................49 
ISSN: 2414-0325. Open educational e-environment of modern University, special edition (2020)

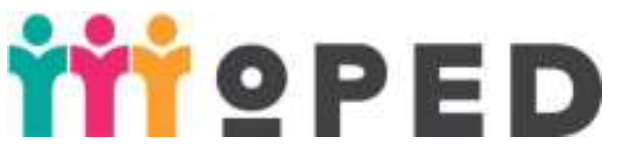

Co-funded by the Erasmus+ Programme of the European Union

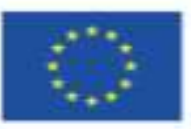

ВИСНОВКИ .50

СПИСОК ВИКОРИСТАНИХ ДЖЕРЕЛ. .52

Додаток 1. Опитувальник «Вхідне опитування університетів MoPED про контингент» .....53 Додаток 2. Шаблон опитувальника для дослідження ресурсів, інноваційного навчання та кращих практик у застосуванні сучасних інструментів ІКТ ..... 


\section{Виконавче резюме}

Даний звіт підготовлено у рамках виконання робочого пакету WP1 проєкту MoPED, містить результати аналізу опитування, проведеного задля виявлення найбільш вживаних інноваційних технологій, кращих педагогічних практик в університетах, що є учасниками проєкту; рекомендації, що дадуть змогу українським партнерам готувати здобувачів вищої освіти конкурентоспроможних на сучасному ринку праці.

Звіт складається зі вступу, списку використаних джерел, двох додатків та семи розділів та висновків:

I. Загальна адміністративна інформація про університет.

II. Організаційні питання.

III. Опис програми та навчальна практика.

IV. Спільноти. Громадська позиція.

$\mathrm{V}$. Технологічні питання.

VI. Система оцінювання.

VII. Навчальна культура

Висновки.

У вступі обгрунтовано мету проведення дослідження, описано етапи його реалізації, спільну діяльність українських університетів - учасників проєкту.

У першому розділі подано статистику контингенту студентів та викладачів українських університетів та зведену таблицю про структуру університетів, наведено описи міжнародних проєктів, що реалізувались науково-педагогічними колективами університетів.

Другий розділ присвячено правовій базі 3 питань використання інноваційних інструментів та технологій навчання, в тому числі впровадження дистанційної форми на державному рівні та на рівні самоврядування університетів.

У третьому розділі зроблена спроба систематизувати описи освітніх програм та практики використання прикладів практичних досліджень та результатів наукових досліджень.

Четвертий розділ спрямований на висвітлення активності навчальних спільнот студентів, виявлення рівня врахування різноманітності студентів, громадської позиції в освітньому процесі, залучення студентів до управлінських рішень та науково-дослідних проєктів.

Розділ п’ятий присвячений з'ясуванню технологічних питань, зокрема тому, як впроваджуються інноваційні методи та освітні технології, наскільки відчутною є підтримка адміністрації університету у питаннях розширення інфраструктури електронного навчання, процесів впровадження IКТ, використання онлайн-середовища (е-портфоліо студента, викладача; електронний кабінет викладача, е-журнал та е-деканат тощо). У цьому ж розділі наводиться аналіз розвитку стартапів та екосистеми в Університеті, а також приклади трансформації освітнього процесу університету, які відбулися завдяки ефективному впровадженню IКТ.

Шостий розділ присвячений аналізу систем оцінювання. Зокрема розглянуто використовувані методики забезпечення якості оцінювання програм 3 використанням 
інноваційних методів та технологій навчання, шляхи оцінювання інноваційного змісту навчання, використання інноваційних методів та технологій навчання, система здійснення контролю та оцінювання програм, що включають інноваційні методи і технології навчання.

У сьомому розділі наводяться кращі практики університетів щодо розвитку навчальної культури, зокрема опис системи стимулювання та підтримки співробітників у використанні електронного навчання та інноваційних методів навчання, індикатори оцінювання сформованості цифрових компетентностей викладачів та студентів.

Основні загальні висновки за результатами проведеного дослідження представлено у розділі Висновки. 


\section{Executive Summary}

This report is prepared as part of the implementation of the WP1 by project MoPED. Report analyses and summarizes the results of the survey, which conducted to identify the most used innovative technologies, best pedagogical practices in the universities - project participates; recommendations which help Ukrainian partners to prepare higher education students for future careers.

The report consists of an Introduction, a Reference, two Annexes, and seven sections:

I. General administrative information about the university.

II Organizational level.

III. Syllabus level and teaching practice.

IV. Community level.

V. Technological level.

VI. Evaluation level.

VII. Educational culture.

Conclusions.

The Introduction substantiates the purpose of the study, describes the stages of its implementation, the joint activities of Ukrainian universities - project participants.

The first section provides statistics proceeding students and teachers contingent of Ukrainian universities and a summary table on the universities structure, describes the international projects implemented by universities` scientists and universities`academic staff.

The second section is devoted to the legal framework on the use of innovative teaching tools and technologies, including the introduction of online learning at the state level and at the university self-government level.

The third section attempts to systematize syllabi descriptions and practice descriptions about using real-life case studies and scientific research results.

The fourth section is aimed at highlighting the students`communities activity, identifying the level of student diversity, the community position in the educational process, involving students in management decisions and research projects.

Section five is devoted to the technological level explanation, in particular, how innovative methods and educational technologies are implemented, what is real the university administration support in expanding the e-learning infrastructure, the implementation of ICT, the use of the online environment (students`e-portfolio, academic instructors`e-portfolio; academic instructors e- office, e- journals and e-dean's system, etc.). The same section provides an analysis of the development of startups and ecosystems at the University, as well as examples of the transformation of the University's educational process, which have occurred through the effective implementation of ICT.

The seventh section provides best universities practices for the development of an educational culture, including a description of the system for incenting and supporting academic staff in the use of e-learning and innovative teaching methods, indicators for formative assessment of academic instructors`and students`digital competences.

The main general conclusions of the study are presented in the Conclusions section. 


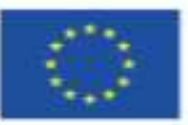

\section{ВСТУП}

Сучасні студенти - покоління центеніалів, це прагматична молодь, яка чітко знає чого хоче від процесу навчання, готова багато працювати, але дуже цінує свій час і категорично проти того, щоб витрачати його на те, що не вважає необхідним для своєї майбутньої професійної діяльності та успішної кар'єри.

Насичення реального світу цифровими пристроями, засобами, системами та налагодження електронно-комунікаційного обміну між ними вимагають цифровізації освіти, як складової цифровізації суспільства в цілому [8]. Для реалізації мети цифровізації, яка полягає у «досягненні цифрової трансформації існуючих галузей економіки та створенні нових галузей, а також трансформації сфер життєдіяльності у нові більш ефективні та сучасні» [9] важливу роль має відігравати саме система освіти.

Метою даного дослідження було виявлення найбільш вживаних, популярних інноваційних технологій, кращих педагогічних практик; порівняння з досвідом університетів ЄC та створення рекомендацій, що дадуть змогу українським партнерам у майбутньому готувати здобувачів вищої освіти конкуренто спроможних на ринку праці.

Дане дослідження проведено задля реалізації однієї з цілей проєкту - ефективної співпраці між педагогічним сектором вищої освіти України та $€ C$, викладачами шкіл та їх об'єднаннями. Перед українськими учасниками проєкту постали завдання: сформулювати розуміння необхідних аспектів для створення профілю компетентності студента в нових дисциплінах, побудувати профілі цифрової компетентності вчителя та викладача університету на основі обміну знаннями, отриманими від партнерів СС.

Для прискорення процесів трансформації освіти під впливом цифровізації Європейський союз запровадив кілька ініціатив. Цифрова система освіти в СС реалізується у рамках «Стратегії ЄС-2020» [4] та її провідних ініціатив: «Цифрова програма для Європи», «Порядок денний для нових навичок та робочих місць», «ннноваційний Союз». «Порядок денний для нових навичок та робочих місць» [1] сприяє безперервному навчанню в Інтернеті, розвитку цифрових компетентностей, інвестиції в інфраструктуру освіти та підтримці конкретних програм підготовки вчителів та їх підвищення кваліфікації.

Для заохочення ефективного цифрового навчання в 2013 році була започаткована, а в 2016 оновлена Європейська платформа цифрових компетентностей для громадян [6]. У 2015 році було розроблено Європейську рамкову програму для цифрових освітніх організацій [3]. Виходячи 3 вищезгаданих заходів, у 2015 році було прийнято широке коло ініціатив, розроблених Європейською стратегією єдиного ринку для підприємств [2], що займаються бізнесом та людськими ресурсами. Ці ініціативи спрямовані на побудову інноваційного суспільства; відкрите та безпечне цифрове середовище; вирішення проблем кібербезпеки; прийняття нового законодавства для єдиного цифрового ринку, європейської економіки даних, онлайн-ринку; розвитку цифрових навичок та можливостей для всіх.

Для спільної роботи з метою зміцнення людського капіталу, працевлаштування та конкурентоспроможності була розроблена «Програма нових навичок для Європи» (New Skills Agenda for Europe: Working together to strengthen human capital, employability and competitiveness) [5], яка посилює існуючі ініціативи та фокусується на цифрових навичках; 


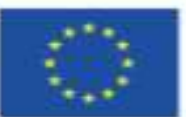

передбачає розширення неформального навчання; підтримує інновації в педагогіці, інституційне співробітництво та мобільність, партнерські стосунки з бізнесом.

В Україні серед десяти ключових компетентностей, які задекларовані Концепцією Нової української школи, $є$ інформаційно-цифрова компетентність, що «передбачає впевнене, а водночас критичне застосування інформаційно-комунікаційних технологій для створення, пошуку, обробки, обміну інформацією на роботі, в публічному просторі та приватному спілкуванні... Розуміння етики роботи 3 інформацією (авторське право, інтелектуальна власність тощо)» [7].

Дослідження проходило у кілька етапів:

1.1. Підготовка анкети - «Вхідне опитування університетів проєкту MOPED про контингент», що передбачало відповіді про контингент університету, зокрема про кількість студентів та професорсько-викладацький склад, який може бути залученим до опитувань за проєктом MoPED. Досліджувані дані допомогли визначити необхідну репрезентативну вибірку для опитування студентів (денної i заочної форм навчання, бакалаврату i магістратури) та викладачів з метою виконання завдань WP1 в рамках проєкту. Окремо було запропоновано вказати кількість студентів бакалаврату денної форми навчання педагогічних спеціальностей та спеціальностей, дотичних до STEM.

1.2. Проведення анкетування у Google-формі (додаток 1, https://docs.google.com/forms/d/e/1FAIpQLSf6IvIdo4lzpNRSZeez3437ZN19GeZ71hRpBEKsizS9 CdhS9w/viewform)

1.3. Аналіз статистичних даних.

2.1. Розробка проєкту шаблону опитувальника для дослідження ресурсів, інноваційного навчання та кращих практик у застосуванні сучасних інструментів IКТ (додаток 2)

2.2. Аналіз шаблонів, заповнених університетами - українськими партнерами

2.3. Обговорення заповнених шаблонів на семінарі «Щодо виконання робочого пакету WP1 у рамках міжнародного проєкту MoPED», що відбувся 11-12 червня 2018 року в Київському університеті імені Бориса Грінченка

2.4. Підготовка підсумкового звіту «Інноваційне навчання та найкращі практики: Вищі навчальні заклади України»

Підсумковий звіт структурований за розділами зазначеними у змісті та на малюнку 1.

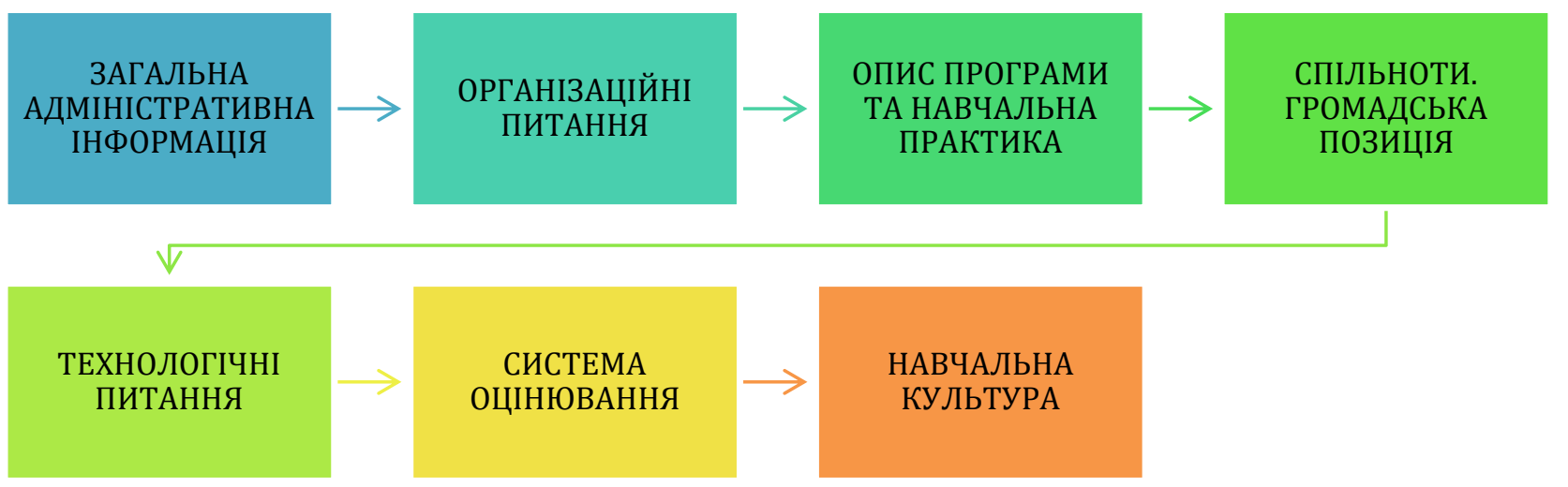

Мал. 1. Структура звіту «Innovative teaching and best practices: Ukraine Universities» 
В рамках виконання завдань проєкту було проведено аналіз рівня використовуваних освітніх програм та кращих педагогічних практик, питання важливості спільнот, обміну педагогічним досвідом між викладачами університету та у підрозділах університетів, технологічні особливості підтримки керівництва університету інноваційної діяльності викладачів, долучення студентів до наукової та проєктної діяльності, рівень використання технічних засобів викладачами українських університетів - партнерів проєкту, актуальні системи оцінювання та пріоритетні напрями формування навчальної культури станом на початок 2018 p. 


\section{І. ЗАГАЛЬНА АДМІНІСТРАТИВНА ІНФОРМАЦІЯ ПРО УНІВЕРСИТЕТ}

Загальну інформацію про Університети, що беруть участь у Проєкті подано в таблиці 1. На малюнку 2 міститься статистика контингенту студентів та викладачів університетівучасників проєкту станом на 1.01.2017 р.

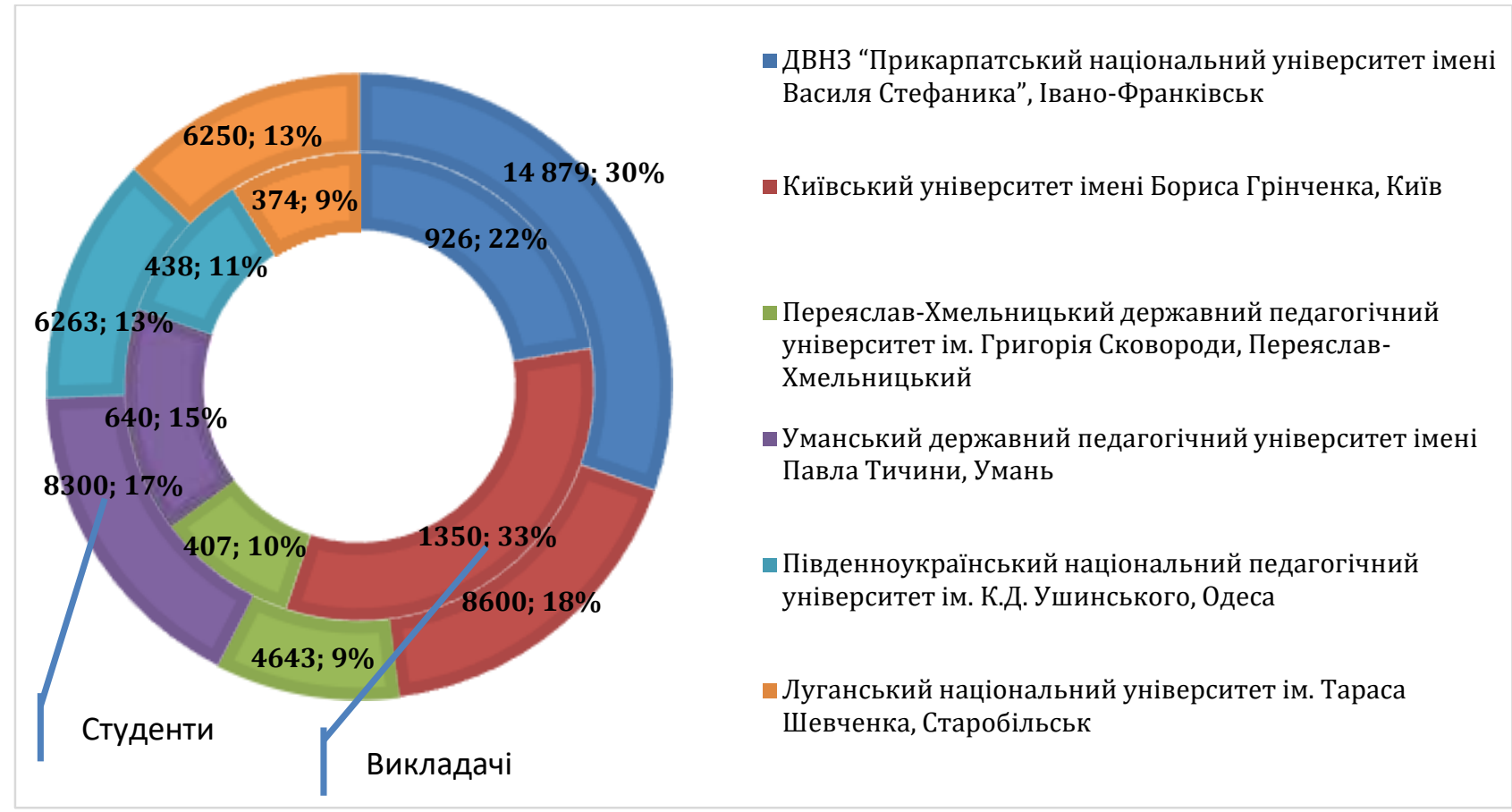

Мал. 2. Контингент студентів та викладачів Університетів, щзо є учасниками Проєкту з різних регіонів України

Таблиця 1

\begin{tabular}{|c|c|c|c|c|c|}
\hline $\begin{array}{c}\text { Універси } \\
\text { тет }\end{array}$ & Повна назва & $\begin{array}{c}\text { Форма } \\
\text { власності }\end{array}$ & $\begin{array}{l}\text { Кількість } \\
\text { студентів }\end{array}$ & $\begin{array}{c}\text { Кількість } \\
\text { викладачів }\end{array}$ & $\begin{array}{c}\text { Назви Інститутів та } \\
\text { факультетів }\end{array}$ \\
\hline $\begin{array}{l}\text { VSPNU } \\
(\mathrm{P} 1)\end{array}$ & $\begin{array}{l}\text { ДВНЗ } \\
\text { "Прикарпатськ } \\
\text { ий } \\
\text { національний } \\
\text { університет } \\
\text { імені Василя } \\
\text { Стефаника", } \\
\text { Івано- } \\
\text { Франківськ/ } \\
\text { Україна }\end{array}$ & $\begin{array}{l}\text { Державний } \\
\text { класичний } \\
\text { університет }\end{array}$ & $\begin{array}{l}\text { Студентів - } \\
14 \quad 879 ; \\
10052 \\
\text { студенти, } \\
\text { які } \\
\text { здобувають } \\
\text { ОР } \\
\text { бакалавра } \\
2854 \\
\text { студенти, - } \\
\text { які } \\
\text { здобувають } \\
\text { ОР } \\
\text { магістра }\end{array}$ & $\begin{array}{l}926 \\
\text { викладачів }\end{array}$ & $\begin{array}{l}4 \text { інститути, } 11 \\
\text { факультетів, } 1 \text { - } \\
\text { університетський коледж } \\
\text { (всього - 16). } \\
\text { Факультети: } \\
\text { економічний факультет, } \\
\text { факультет іноземних мов, } \\
\text { педагогічний факультет, } \\
\text { філософський факультет, } \\
\text { факультет математики та } \\
\text { інформатики, факультет } \\
\text { філологї, факультет } \\
\text { туризму, фізико- } \\
\text { технічний факультет, } \\
\text { факультет історії, } \\
\text { політології і міжнародних }\end{array}$ \\
\hline
\end{tabular}




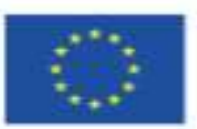

\begin{tabular}{|c|c|c|c|c|c|}
\hline $\begin{array}{c}\text { Універси } \\
\text { тет } \\
\end{array}$ & Повна назва & $\begin{array}{c}\text { Форма } \\
\text { власності }\end{array}$ & $\begin{array}{l}\text { Кількість } \\
\text { студентів }\end{array}$ & $\begin{array}{c}\text { Кількість } \\
\text { викладачів } \\
\end{array}$ & $\begin{array}{c}\text { Назви Інститутів та } \\
\text { факультетів }\end{array}$ \\
\hline & & & & & $\begin{array}{l}\text { відносин, факультет } \\
\text { природничих наук, } \\
\text { факультет фізичного } \\
\text { виховання і спорту. } \\
\text { Інститути: Навчально- } \\
\text { науковий інститут } \\
\text { мистецтв, Інститут } \\
\text { післядипломної освіти та } \\
\text { довузівської підготовки, } \\
\text { Навчально-науковий } \\
\text { юридичний інститут, } \\
\text { Коломийський } \\
\text { навчально-науковий } \\
\text { інститут. Івано- } \\
\text { Франківський коледж } \\
\text { ПНУ імені Василя } \\
\text { Стефаника }\end{array}$ \\
\hline $\begin{array}{l}\text { BGKU } \\
\text { (P5) }\end{array}$ & $\begin{array}{l}\text { Київський } \\
\text { університет } \\
\text { імені Бориса } \\
\text { Грінченка / } \\
\text { Київ / Україна }\end{array}$ & $\begin{array}{l}\text { Класичний } \\
\text { університет, } \\
\text { муніципаль } \\
\text { на власність }\end{array}$ & $\begin{array}{l}\text { Понад } 8600 \\
\text { студентів }\end{array}$ & $\begin{array}{l}\text { Понад } 1350 \\
\text { викладачів }\end{array}$ & $\begin{array}{l}\text { Факультети - } 4 \\
\text { (інформаційних } \\
\text { технологій та управління; } \\
\text { історико-філософський; } \\
\text { здоров'я, фізичного } \\
\text { виховання і спорту; права } \\
\text { та міжнародних } \\
\text { відносин), } \\
\text { інститути- 6 } \\
\text { (педагогічний, людини, } \\
\text { журналістики, мистецтва, } \\
\text { філологї, післядипломної } \\
\text { педагогічної освіти) і } \\
\text { Університетський } \\
\text { коледж (всього - 11) }\end{array}$ \\
\hline $\begin{array}{l}\text { PHDPU } \\
\text { (P6) }\end{array}$ & $\begin{array}{l}\text { Переяслав- } \\
\text { Хмельницький } \\
\text { державний } \\
\text { педагогічний } \\
\text { університет ім. } \\
\text { Григорія } \\
\text { Сковороди/ } \\
\text { Переяслав- } \\
\text { Хмельницький } \\
\text { / Україна }\end{array}$ & $\begin{array}{l}\text { Державний } \\
\text { педагогічни } \\
\text { й } \\
\text { університет }\end{array}$ & $\begin{array}{l}4643 \\
\text { студента }\end{array}$ & $\begin{array}{l}407 \\
\text { викладачів }\end{array}$ & 7 факультетів \\
\hline $\begin{array}{l}\text { PTUSPU } \\
\text { (P7) }\end{array}$ & $\begin{array}{l}\text { Уманський } \\
\text { державний } \\
\text { педагогічний } \\
\text { університет }\end{array}$ & $\begin{array}{l}\text { Державний } \\
\text { педагогічни } \\
\text { й } \\
\text { університет }\end{array}$ & $\begin{array}{l}\text { понад } 8300 \\
\text { студентів }\end{array}$ & $\begin{array}{l}\text { понад } \quad 640 \\
\text { викладачів }\end{array}$ & $\begin{array}{l}1 \text { інститут та } 11 \\
\text { факультетів }\end{array}$ \\
\hline
\end{tabular}




\section{ํํ음}

\section{Co-funded by the Erasmus+ Programme} of the European Union

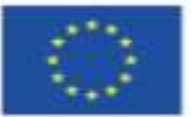

\begin{tabular}{|c|c|c|c|c|c|}
\hline $\begin{array}{c}\text { Універси } \\
\text { тет }\end{array}$ & Повна назва & $\begin{array}{c}\text { Форма } \\
\text { власності }\end{array}$ & $\begin{array}{l}\text { Кількість } \\
\text { студентів }\end{array}$ & $\begin{array}{c}\text { Кількість } \\
\text { викладачів }\end{array}$ & $\begin{array}{c}\text { Назви Інститутів та } \\
\text { факультетів }\end{array}$ \\
\hline & $\begin{array}{l}\text { імені Павла } \\
\text { Тичини } \\
\text { /Умань/ } \\
\text { Україна }\end{array}$ & & & & \\
\hline $\begin{array}{l}\text { SUNPUU } \\
\text { (P8) }\end{array}$ & $\begin{array}{l}\text { Південноукраїн } \\
\text { ський } \\
\text { національний } \\
\text { педагогічний } \\
\text { університет ім. } \\
\text { К.Д. } \\
\text { Ушинського / } \\
\text { Одеса } \\
\text { Україна }\end{array}$ & $\begin{array}{l}\text { Державний } \\
\text { педагогічни } \\
\text { й } \\
\text { університет }\end{array}$ & $\begin{array}{l}6263 \\
\text { студентів }\end{array}$ & $\begin{array}{l}438 \\
\text { викладачів }\end{array}$ & $\begin{array}{l}9 \text { факультетів та } 2 \\
\text { інститути }\end{array}$ \\
\hline $\begin{array}{l}\text { LTSNU } \\
\text { (P9) }\end{array}$ & $\begin{array}{l}\text { Луганський } \\
\text { національний } \\
\text { університет ім. } \\
\text { Тараса } \\
\text { Шевченка } \\
\text { /Старобільськ / } \\
\text { Україна }\end{array}$ & $\begin{array}{l}\text { Державний } \\
\text { класичний } \\
\text { університет }\end{array}$ & $\begin{array}{l}6250 \\
\text { студентів }\end{array}$ & $\begin{array}{l}374 \\
\text { викладачів }\end{array}$ & $\begin{array}{l}8 \text { навчально- } \\
\text { дослідницьких } \\
\text { інститутів, } 3 \text { факультети }\end{array}$ \\
\hline
\end{tabular}

Проскти, що відносяться до інноваційного викладання та / або застосування технологій у навчанні / викладанні

В університетах було розпочато проєкти (таблиця 2), що стосуються інноваційного викладання та можуть бути цікавими для ознайомлення іншими:

Таблиця 2

\begin{tabular}{|l|l|l|}
\hline \multicolumn{1}{|c|}{ Університет } & \multicolumn{1}{|c|}{ Назва проскту } & \multicolumn{1}{|c|}{ Опис проєкту, результати } \\
\hline VSPNU (P1) & Міжнародний & http://observatorium.pu.if.ual \\
& проєкт & \\
Прикарпатського & \\
& національного \\
& університету імені & \\
& Василя Стефаника & \\
& та Варшавського \\
& університету \\
& «Міжнародний & \\
& науковий центр \\
& «Обсерваторія» & \\
\hline
\end{tabular}




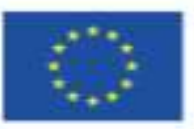

\begin{tabular}{|c|c|c|}
\hline & $\begin{array}{l}\text { Проєкт «Розробка } \\
\text { навчальних } \\
\text { курсів, пов'язаних } \\
3 \text { вивченням } \\
\text { вбудованих } \\
\text { систем та } \\
\text { впровадженням } \\
\text { інноваційних } \\
\text { віртуальних } \\
\text { підходів } \\
\text { інтеграції до } \\
\text { досліджень, } \\
\text { освіти } \\
\text { виробництва та в } \\
\text { Україні, Грузії, } \\
\text { Вірменії } \\
\text { (DESIRE) - для } \\
\text { розвитку } \\
\text { STEAM-освіти }\end{array}$ & $\begin{array}{l}\text { В Університеті обладнано лабораторію вбудованих } \\
\text { систем, яка активно використовується у навчальному } \\
\text { процесі для вивчення основ робототехніки, 3D-друку, } \\
\text { дистанційних лабораторій. Розроблені нові навчальні } \\
\text { програми та відповідна методологічна підтримка } \\
\text { впровадження інноваційних курсів для вивчення } \\
\text { вбудованих } \\
\text { Створено нові спеціальності та спеціалізації на факультеті } \\
\text { інформаційних технологій і управління (спеціалізація } \\
\text { Internet of Things, спеціальності Кібербезпека). } \\
\text { Проєкт «Розробка навчальних курсів з вбудованих систем } \\
3 \text { використанням інноваційних віртуальних підходів для } \\
\text { інтеграції науки, освіти та промисловості в Україні, } \\
\text { Грузії, Вірменії 544091-ТEMPUS-1-2013-1-ВE-TEMPUS- } \\
\text { JPCR» } \\
\text { http://tempus.kubg.edu.ua/ }\end{array}$ \\
\hline & $\begin{array}{l}\text { Модуль «Якість } \\
\text { вищої освіти та } \\
\text { експертний } \\
\text { супровід } \\
\text { забезпечення: руі } \\
\text { України до } \\
\text { Свропейського } \\
\text { Союзу» програми } \\
\text { «Еразмус+: Жан } \\
\text { Моне» }\end{array}$ & 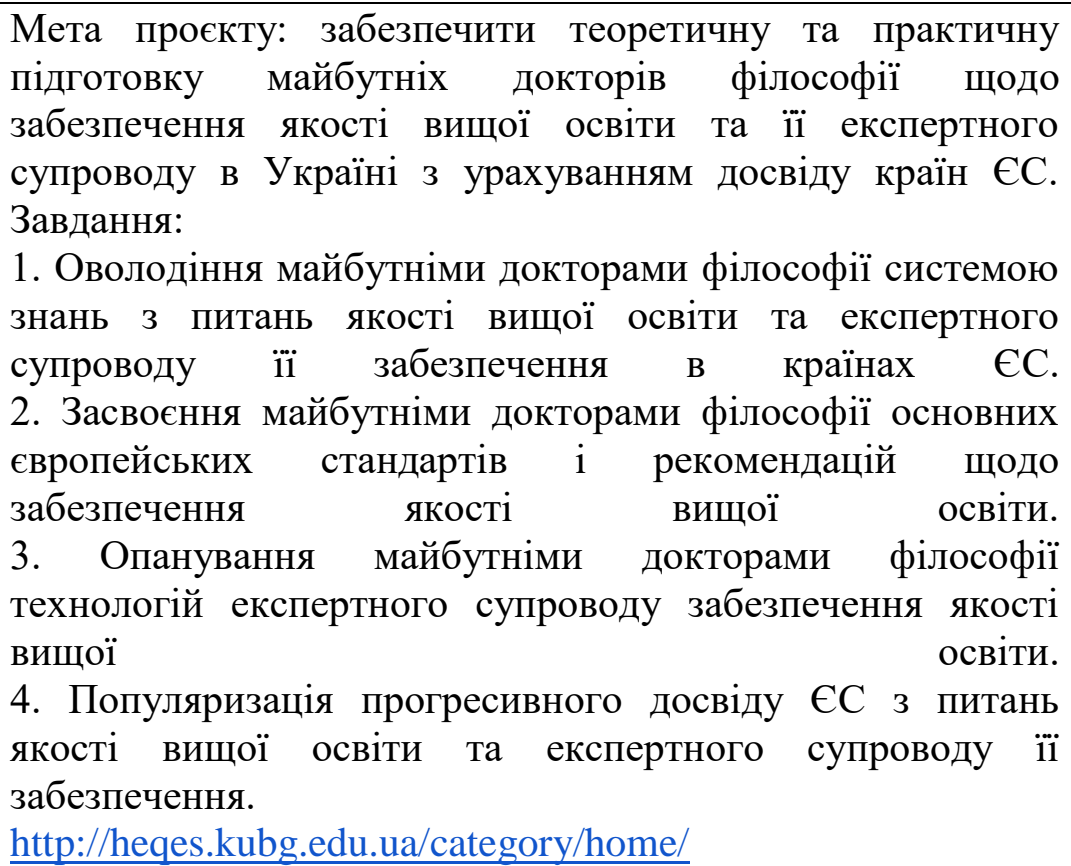 \\
\hline BGKU (P5) & 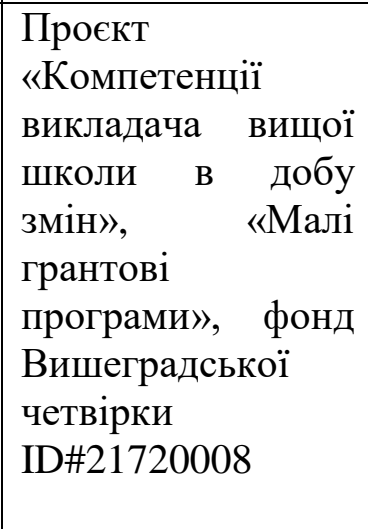 & $\begin{array}{l}\text { Метою проєкту «Компетенції викладача вищої школи в } \\
\text { добу змін» є визначення та діагностика комплексу } \\
\text { компетентностей професорів вищих навчальних закладів, } \\
\text { які відповідають вимогам часу та подальшої } \\
\text { стандартизації ї діяльності у трьох країнах } \\
\text { Вишеградської групи (Польща, Чехія та Словаччина) та } \\
\text { України. } \\
\text { Визначено основні ідеї профілю наступним чином: } \\
\text { педагогічна культура та етика, професійне прийняття } \\
\text { рішень, відповідальність за наслідки, навички керівництва } \\
\text { та громадянське ставлення. }\end{array}$ \\
\hline
\end{tabular}




\begin{tabular}{|c|c|c|}
\hline & & $\begin{array}{l}\text { Підготовлено рекомендації щодо формування 5-ти груп } \\
\text { компетентностей викладачів вищої школи. } \\
\text { Проєкт ID № } 21720008 \text { «Компетентність викладача вищої } \\
\text { школи в добу змін» } \\
\text { http://histecc.kubg.edu.ua/ }\end{array}$ \\
\hline PHDPU (P6) & EcoBRU & $\begin{array}{l}\text { Проєкт ЕсоBRU сприяє постійній підготовці вчителів } \\
\text { професійно-технічних навчальних закладів та вчителів } \\
\text { середніх школах у Білорусі, Росії та Україні. Для цієі } \\
\text { цільової групи розробляється та впроваджується програма } \\
\text { електронного навчання - курси підвищення кваліфікації в } \\
\text { галузі екологічної освіти. } \\
\text { https://ecobruPHDPU (P6).webnode.com.ua/ }\end{array}$ \\
\hline PTUSPU (P7) & $\begin{array}{l}\text { Шкільний вчитель } \\
\text { нового покоління }\end{array}$ & 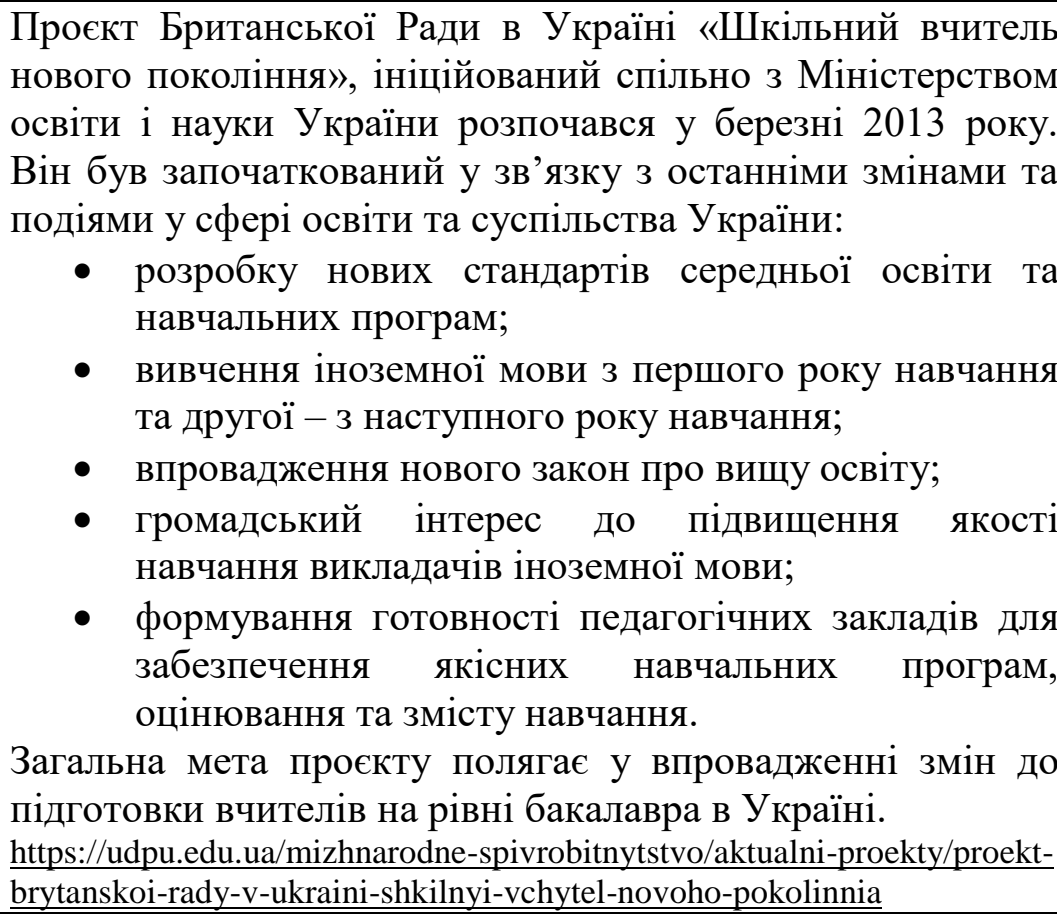 \\
\hline SUNPUU (P8) & $\begin{array}{l}\text { Назва проєкту - } \\
\text { Східне } \\
\text { партнерство в } \\
\text { рамках проєкту } \\
\text { «Педагогічні } \\
\text { інновації у сфері } \\
\text { інклюзивної } \\
\text { освіти» } \\
\text { (INOVEST) } \\
530417 \text { - Tempus - } \\
1 \text { - 2012 - 1 - DE- } \\
\text { TEMPUS-SMHES } \\
\text { (2012-2016) }\end{array}$ & $\begin{array}{l}\text { Розроблено три програми } 3 \text { підготовки курсів } \\
\text { «Впровадження педагогічних інновацій в інклюзивній } \\
\text { освіті» для викладачів, менеджерів та промоутерів, } \\
\text { науково-методичний комплекс, що складається } 315 \\
\text { навчальних посібників, } 6 \text { спеціалізованих лабораторних } \\
\text { комплексів; опубліковано монографію «Обласні } \\
\text { технології в інклюзивній освіті». } \\
\text { Посилання на результати проєкту: www.pdpu.edu.ua }\end{array}$ \\
\hline LTSNU (P9) & $\begin{array}{l}\text { Електронне } \\
\text { навчання та } \\
\text { змішане навчання } \\
\text { в ЛНУ }\end{array}$ & www.do.luguniv.edu.ua \\
\hline
\end{tabular}




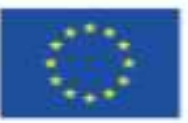

\section{II. ОРГАНІЗАЦІЙНІ ПИТАННЯ}

\section{Правова база для використання інноваційних інструментів та технологій навчання на Державному рівні}

1. Закони України «Про освіту» http://zakon5.rada.gov.ua/laws/show/2145-19, «On Higher Education» http://zakon0.rada.gov.ua/laws/show/1556 -18.Ці закони визнають автономію навчальних закладів при виборі дисциплін для підготовки конкурентного випускника. Важливою також $є$ співпраця на випускних іспитах з представниками бізнесу.

2. Положення про порядок здійснення інноваційних освітніх заходів (http://zakon2.rada.gov.ua/laws/show/z0946-00)

3. «Цифрова адженда Україна-2020», яка передбачає стратегічне завдання - подолати технологічний розрив між Україною та розвиненими країнами. У документі вказується необхідність використання «цифрових» технологій в освіті як одного 3 найважливіших і стійких тенденцій світового освітнього процесу.

4. Постанова Кабінету Міністрів України «Концепція «Нова українська школа». Головна мета якої створити школу, в якій буде приємно навчатись і яка дасть учням не тільки знання, як це відбувається зараз, але і здатність застосовувати їх у житті.

В усіх університетах розроблена стратегія розвитку та Положення про організацію освітнього процесу, в яких відзначається необхідність впровадження інновацій в освітній процес. Цікавими для обміну досвідом є положення, які відображені в таблиці 3.

Таблиця 3

\begin{tabular}{|c|c|}
\hline Університет & Положення, прийняті Університетом \\
\hline VSPNU (P1) & 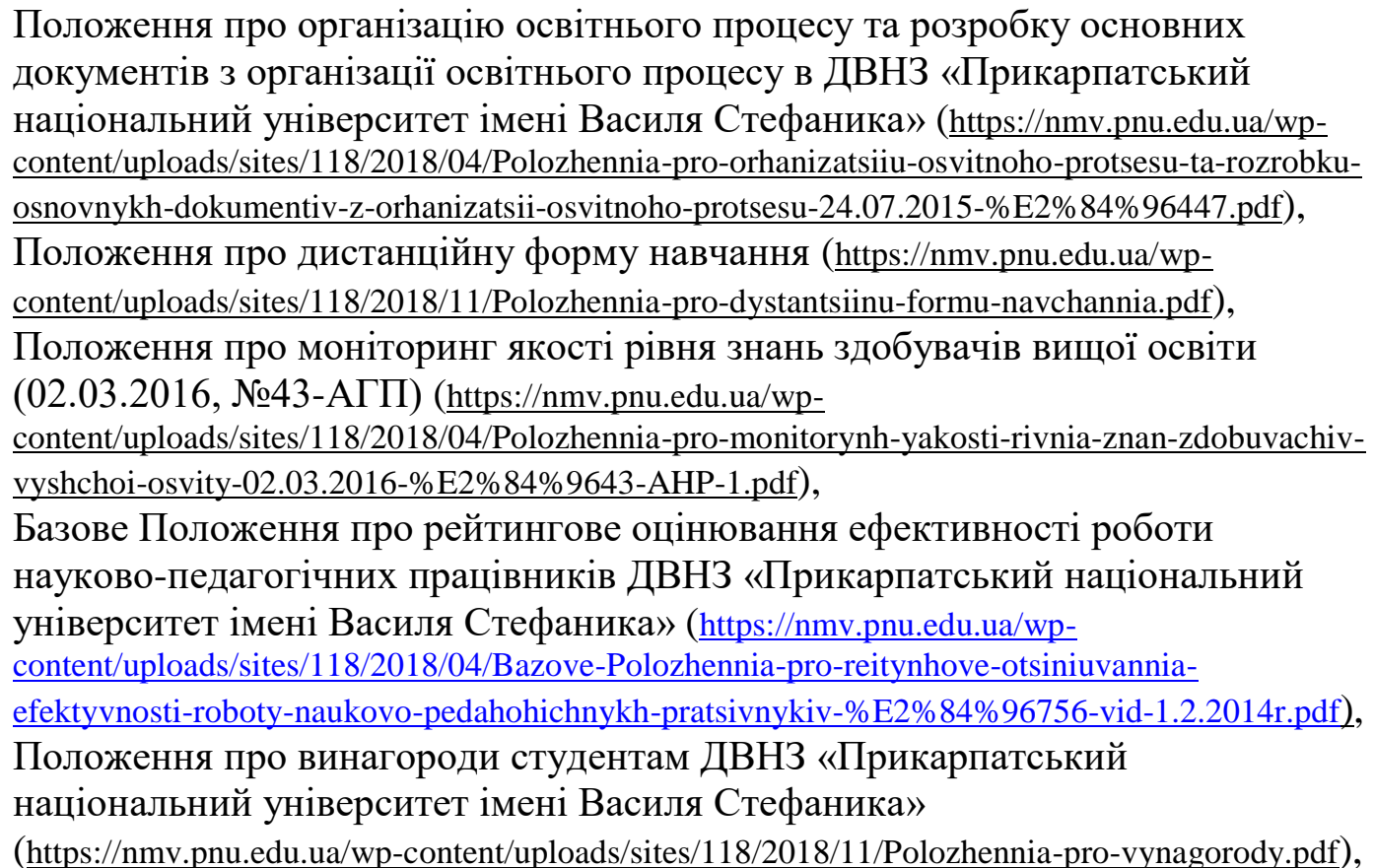 \\
\hline
\end{tabular}




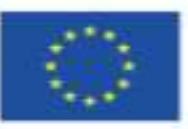

\begin{tabular}{|c|c|}
\hline Університет & Положення, прийняті Університетом \\
\hline & $\begin{array}{l}\text { Положення про підтримку наукових і науково-педагогічних працівників } \\
\text { університету, які публікують праці у виданнях, що входять до } \\
\text { наукометричних баз Scopus та Web of Science } \\
\text { (https://nauka.pnu.edu.ua/\%D0\%BF\%D0\%BE\%D0\%BB\%D0\%BE\%D0\%B6\%D0\%B5\%D0\%BD } \\
\text { \%D0\%BD\%D1\%8F/), } \\
\text { Положення про діяльність молодих вчених (https://nauka.pnu.edu.ua/wp- } \\
\text { content/uploads/sites/122/2018/06/molodi_vcheni.pdf), } \\
\text { Положення про підготовче відділення для iноземних громадян } \\
\text { (https://nauka.pnu.edu.ua/\%D0\%BF\%D0\%BE\%D0\%BB\%D0\%BE\%D0\%B6\%D0\%B5\%D0\%BD } \\
\text { \%D0\%BD\%D1\%8F/), } \\
\text { «План розвитку Прикарпатського національного університету імені Василя } \\
\text { Стефаника» на 2011-2020 роки, } \\
\text { «Положення про електронну бібліотеку Прикарпатського національного } \\
\text { університету ім. Василя Стефаника» (2013 р.) та ін. }\end{array}$ \\
\hline BGKU (P5) & 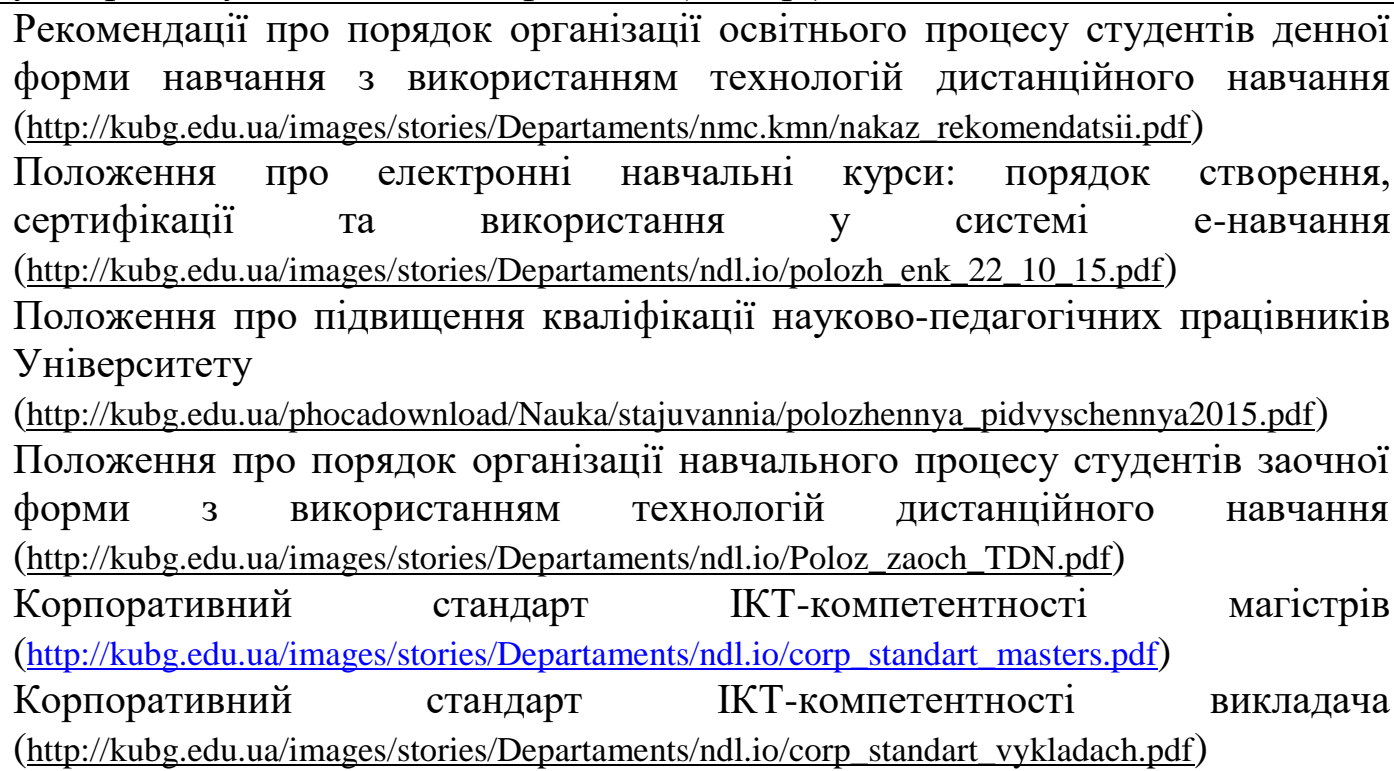 \\
\hline LTSNU (P9) & $\begin{array}{l}\text { Положення про уніфіковані вимоги до електронних курсів, про захист } \\
\text { авторських правил } \\
\text { Положення про експертизу якості електронних матеріалів. }\end{array}$ \\
\hline
\end{tabular}

\section{Правова основа для проведення занять за дистанційною формою.}

У 5-ти університетах інтернет-навчання розглядається лише як додаткова активність до традиційних годин у аудиторії.

B BGKU (P5) прийнято Положення, відповідно до якого викладачі можуть проводити половину традиційних годин на заняття в режимі онлайн (50\% очних/50\% дистанційних) при наявності створених ЕНК. Які відповідають затвердженим вимогам. Такі заняття ставлять у розклад - як дистанційні. Детальні правила, викладені у документі «Рекомендації про порядок організації освітнього процесу студентів денної форми навчання 3 використанням технологій дистанційного навчання». 


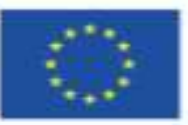

В 5-ти університетах не передбачена можливість визнання сертифікатів, що отримані студентами після завершення зовнішніх онлайн-курсів (наприклад, MOOCs).

Цікавою є практика розв'язання такої проблеми в BGKU (P5). Так у Положенні про організацію освітнього процесу зафіксовано таку можливість для всіх навчальних дисциплін, за умови, що програма курсу відповідає відповідній навчальній чи освітній програмі, що затверджена в Університеті. Крім того, деякі навчальні дисципліни IКТ спрямування пропонується студентам опановувати на відповідних сайтах корпорації, наприклад Майкрософт, Cisco, IBM. 3 означеними корпораціями Університет має підписані відповідні Угоди, які надають доступ студентам та викладачам до корпоративних навчальних ресурсів, де фіксуються успіхи студентів щодо виконання завдань. Так, у рамках співпраці Київського університету імені Бориса Грінченка та Microsoft Imagine Academy 1242 співробітники та студенти пройшли 5529 курсів. 40 осіб склали міжнародний сертифікаційний іспит Microsoft. Університет визнає сертифікати, отримані студентами після завершення зовнішніх онлайнкурсів на інших платформах дистанційного навчання. Сертифікат може бути зарахований як один з модулів у відповідній темі дисципліни.

У Положенні про організацію освітнього процесу в Київському університеті імені Бориса Грінченка вказуються конкретні моменти, що сприяють впровадженню інновацій:

- Перелік дисциплін навчального плану складається 3 двох частин - обов'язкової та вибіркової. Вибіркова частина навчального плану становить не менше 25 \% від загальної кількості кредитів ECTS, передбачених для певного рівня вищої освіти.

- Вибіркову частину навчального плану студент формує самостійно 3 переліку дисциплін (додаткових спеціалізацій тощо) за встановленою в Університеті процедурою. Університет у межах ліцензованої спеціальності може запроваджувати спеціалізації, перелік яких зазначається в навчальному плані.

- Робоча програма доступна студентам для ознайомлення і є обов'язковою складовою електронного навчального курсу (далі - ЕНК), розміщеного в електронному середовищі Університету.

\section{Система контролю якості навчальних матеріалів, рівня задоволення студентів навчальними матеріалами, що підготовлені викладачами}

B VSPNU (P1), PHDPU (P6) проводиться опитування студентів щодо якості надання освітніх послуг, зокрема рівня викладання навчальних дисциплін, задоволеності студентів підготовленими навчальними матеріалами, пропонованими методами і формами роботи. Ця інформація береться до уваги під час проведення конкурсу на заміщення вакантних посад серед професорсько-викладацького складу в університеті.

B BGKU (P5) запроваджено систему оцінювання навчальних матеріалів, до якої входять:

1. Система оцінювання електронних навчальних курсів (ЕНК), розміщених в LMS Moodle, що базується на застосуванні розробленого в Університеті «Положення про електронні навчальні курси: порядок створення, сертифікації та використання у 


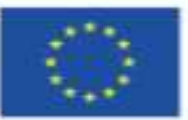

системі е-навчання», затвердженого Вченою радою університету. Зокрема, створено групи експертів, які надають експертизу та перевіряють ЕНК у два етапи:

- Колеги автора з відповідної кафедри оцінюють науковий рівень навчальних матеріалів курсу, проводять аналіз відповідності змісту державним стандартам освіти, цілям і задачам курсу. Експерти мають здійснити змістовно-наукову експертизу та персонально в онлайн заповнити форму «змістовно-наукова експертиза», результати якої розглядаються на засіданні кафедри.

- За умови позитивного рішення кафедри щодо якості навчальних матеріалів курсу на наступному етапі проводиться структурно-функціональна експертиза та методична експертиза ЕНК. Головне завдання полягає у перевірці наявності, якості та функціонування всіх підготовлених складових ЕНК, встановленого доступу до завдань, правильного налаштування ресурсів тощо.

2. Система автоматизованого збирання та аналізу статистики діяльності викладачів та студентів в ЕНК, що розміщені в LMS Moodle.

3. Систематичне, двічі на рік, оцінювання студентами підготовлених викладачами навчальних матеріалів ЕНК, за допомогою спеціально розробленого опитувальника.

Всі результати враховуються в системі е-Порфоліо викладача та при підведенні підсумків конкурсу «Лідер року», які впливають на нарахування викладачам матеріальних надбавок на наступний рік та відповідних премій.

B PTUSPU (P7) впровадження процедури оцінки якості освітніх послуг та рейтингу викладачів «Викладач очима студентів»; проводиться анонімний опитувальник, результати якого визначаються у відсотках і оголошуються на Вченій раді університету.

B SUNPUU (P8) існує спеціальний підрозділ, який забезпечує контроль за студентами задоволеності підготовленими матеріалами, отримується відповідна статистика.

B LTSNU (P9) така система включає:

- експертиза електронного курсу на кафедрі (включає аналіз контенту, обговорення та рішення на засіданні кафедри);

- експертна комісія Університету (аналіз відповідності загальним вимогам до курсів, визнає цей курс як навчально-методичне видання);

- зовнішня експертна оцінка;

- відгуки від студентів (Опитування проводиться вибірково за допомогою lime.luguniv.edu.ua).

\section{Спеціальний підрозділ підтримки в університеті інноваційних методів та технології навчання}

У VSPNU (P1) існує навчально-науковий центр якості надання освітніх послуг та дистанційного навчання (http://www.d-learn.pu.if.ua/index.php), інформаційнообчислювальний відділ (http://cit.pu.if.ua/), відділ інтелектуальної власності та інновації, НКП «Наноматеріали», спільна науково-дослідна лабораторія фізики магнітних плівок Інституту 
металофізики ім. Г.В. Курдюмова НАН України та ДВНЗ «Прикарпатський національний університет імені Василя Стефаника», Навчально-дослідний центр напівпровідникового матеріалознавства (НДСЦМ), Ботанічний сад, Дендрологічний парк ім. З.Павлика, лабораторія когнітивного моделювання, лабораторія “Гірська школа". Науковий парк «Прикарпатський

університет» (https://nauka.pnu.edu.ua/\%D0\%BD\%D0\%B0\%D1\%83\%D0\%BA\%D0\%BE\%D0\%B2\%D0\%B8\% D0\%B9-\%D0\%BF\%D0\%B0\%D1\%80\%D0\%BA/) як організація 3 обмеженою відповідальністю здійснює такі види діяльності: дослідження та експериментальні розробки в галузі біотехнології; лізинг інтелектуальної власності та аналогічних продуктів, за винятком авторських прав; організація з'їздів та виставок тощо. Міжнародний науковий центр «Обсерваторія», створений спільними силами Прикарпатського національного університету ім. Василя Стефаника i Студіями східноєвропейських досліджень Варшавського університету, який має на меті проведення системних наукових досліджень $\mathrm{i}$ їх впровадження в освітню практику.

При науковій бібліотеці VSPNU (P1) функціонує відділ інформаційних технологій та комп'ютерного забезпечення (http://lib.pu.if.ua/structure.php), який допомагає викладачам i студентам у пошуку та впровадженні освітніх інновацій. Основні його функції: підтримка роботи автоматизованої бібліотечної системи «УФД/Бібліотека»; організація комплексу робіт з надання технічної допомоги підрозділам бібліотеки; забезпечення функціонування локальної мережі та комп'ютерної техніки бібліотеки; переведення друкованих видань в електронну форму; ретрокаталогізація активних фондів бібліотеки; видавнича діяльність (комп'ютерний набір, верстка, технічна редакція видань бібліотеки), підтримка та супроводження сайту бібліотеки; підтримка функціонування електронного читального залу.

У BGKU (P5) є спеціальні підрозділи підтримки інноваційних методів та технологій навчання:

- Центр ІКТ-компетентностей та Науково-дослідна лабораторія інформатизації освіти http://kubg.edu.ua/struktura/pidrozdili/ndl-informatizatsiji-osviti/pro-pidrozdil.html, $\quad$ які розробляють та оновлюють програми, проводять семінари, майстер-класи підвищення кваліфікації викладачів 3 використання інноваційних педагогічних технологій та розробляють спеціальні відкриті електронні курси:

- «ІКТ на заняттях у закладі вищої освіти»

- «Актуальні питання та тенденції розвитку освіти вищої школи»

- Змістовий модуль «Інформаційні та комунікаційні технології»,

- «Електронне навчально-наукове середовище сучасного університету»,

- «Використання SMART Technologies» у тренувальному центрі SMART.

B PHDPU (P6) створено відділ моніторингу якості інформаційних технологій та освіти, який вирішує питання активізації освітньої та пізнавальної діяльності учнів; створення умов для широкого впровадження сучасних освітніх технологій у навчальний процес.

В PTUSPU (P7) створено польсько-українська науково-дослідна лабораторія психодидактики, лабораторія модернізації початкової школи, науково-методичний центр інноваційних освітніх технологій. Вони пропонують наступну підтримку: проведення науково-методичних семінарів та конференцій різних рівнів; залучення студентів до наукової 
роботи; забезпечення співпраці з вчителями шкіл; формування банку науково-методичних та навчально-методичних матеріалів.

B SUNPUU (P8) науково-методична комісія вивчає впровадження інноваційних методів та технології навчання. Кафедра інноваційних методів та технології навчання природничих дисциплін та відділ інформаційних технологій забезпечують особливу підтримку інноваційних навчально-технологічних інструментів. Ця підтримка сприяє успішному інноваційному досвіду в педагогіці

B LTSNU (P9) створено лабораторію дистанційного навчання (включена в навчальний відділ), співробітники якої проводять консультації та здійснюють методичну та технічну підтримку студентів та академічних інструкторів (викладачів) в LMS Moodle, здійснює підготовку студентів та вчителів для використання нових технологій у освітньому процесі.

\section{Програми, що підтримують інноваційні методи та технології навчання}

B BGKU (Р5) створено відкриті курси на Вікі-платформі університету: «Представлення результатів наукових досліджень магістрів 3 використанням ІКТ»; Науково-дослідне навчання, Взаємооцінювання; Розвиток критичного мислення; «Практика студентів», «Пошук навчально-наукових матеріалів в інтернеті», «Створення відеолекцій» тощо.

Була створена нова спеціалізація магістерської програми «Управління електронним навчанням», де використовуються інноваційні методи навчання: групова робота, проблемне навчання, ігрові технології, навчальні тренінги, формування оцінки, метод проєктів, змішане навчання, перевернутий клас.

у 2017 р. в рамках Впровадження нової освітньої стратегії Університету було створено 42 центри компетенцій, 8 з них за напрямком IКТ:

- Лабораторія вбудованих систем

- Центр основ управління (з використанням IКТ)

- Центр реінжинірингу бізнес-процесів (з використанням IКТ)

- Центр економічної дидактики (з використанням IКТ)

- Центр банківських та фінансових послуг (з використанням IКТ)

- Центр мультимедійних технологій

- Центр сучасних комунікацій

- Навчальна лабораторія інформаційних технологій у музичному мистецтві.

B PHDPU (P6) всі навчальні програми (курси) включені в модульне навчальне середовище Moodle, що дозволяє більш широко використовувати набір інструментів електронного навчання. Підтримуються такі курси: «Нові педагогічні технології», «Педагогіка», «Історія педагогіки», «Профілактична педагогіка», «Соціальна робота у сфері дозвілля», «Педагогіка вищої школи», «Основи інклюзивної освіти», «Методологія соціально-педагогічної роботи», «Соціальна педагогіка», «Соціально-педагогічна робота 3 групами ризику», «Робота спеціально-реабілітаційних служб».

Використовуються наступні інноваційні навчально-технологічні інструменти: Tagul, карти пам'яті, створені Coggle, Goconqr, Thinglink, Padlet, інноваційні педагогічні технології (інтерактивні, інформаційні та комунікаційні технології, інтернет-технології тощо). 
B PTUSPU (P7) - 100\% навчальних курсів підтримують інноваційні методики. Всі навчальні курси освітніх програм, за якими здійснюється підготовка студентів в університеті, передбачають впровадження інноваційних методик та технологій навчання.

B SUNPUU (P8) підтримуються 3 практичні курси 3 методики викладання всіх університетських дисциплін.

B LTSNU (Р9) всі навчальні програми підтримуються курсами електронного навчання за допомогою інноваційних методів та технології навчання (оскільки університет змінював місце розташування), також коворкинг центр та підрозділ з неформальної освіти.

\section{Підтримка інтелектуальної власності в університетах}

B VSPNU (P1), BGKU (P5) проводиться експертиза дипломних/магістерських робіт на плагіат.

В VSPNU (P1) у структурі наукового відділу університету функціонує відділ інтелектуальної власності та інновацій як окремий підрозділ, при науковій частині університету - патентно-ліцензійний підрозділ, який надає відповідні послуги.

B BGKU (P5) розроблено «Декларації про академічну доброчесність», які підписують викладачі і студенти. Створена та функціонує база даних «База магістерських робіт. Університетська бібліотека виконує перевірку на виявлення збігів/ідентичності/схожості за допомогою системи Unicheck.

В більшості університетів відсутній спеціальний підрозділ щодо прав інтелектуальної власності для академічних інструкторів (викладачів), разом з тим всі Університети надають підтримку в галузі прав інтелектуальної власності викладачам.

B PHDPU (P6) цими питаннями займається підрозділи, які відповідають за організацією науково-дослідницької діяльності.

B PTUSPU (P7) у науковому відділі функціонує патентно-ліцензійний підрозділ, в якому викладачі та студенти отримують методичну допомогу у створенні об'єктів інтелектуальної власності. Протягом 2016-2017 років було зареєстровано 12 винаходів та отримано патенти на корисні моделі України. Крім того, діє «Кодекс академічної доброчесності Уманського державного педагогічного університету імені Павла Тичини», проводиться експертиза кваліфікаційних робіт за допомогою системи Anti-Plagiarism.

\section{Впровадження інноваційних інструментів та технологій навчання}

B VSPNU (P1) є Науковий парк «Прикарпатський університет», навчально-методичний відділ управління проєктами (https://projects.pnu.edu.ua/), Проєктно-освітній центр розвитку інновацій та інвестицій «Агенти змін» Прикарпатського університету. Ініціативність щодо впровадження інноваційних технологій навчання (викладання) у роботі університету також підтримує науково-методичний відділ університету.

B BGKU (P5) створено команду, яка забезпечує впровадження інноваційних інструментів та технологій навчання, здійснює оцінку їх результатів. 
Команда складається 3 проректора 3 інформатизації навчально-наукової та управлінської діяльності, Науково-дослідної лабораторії інформатизації освіти (НДЛ IO) та помічників керівників структурних підрозділів з ІКТ, які здійснюють координацію завдань проректора та беруть участь у спільній діяльності щодо інформаційних технологій разом із співробітниками НДЛ IО.

НДЛ IO BGKU (P5) розробляє плани спеціальних курсів, семінарів, майстер-класів для підвищення кваліфікації викладачів, оголошує набір, здійснює електронний запис учасників, розробляє спеціальні відео та інші види методичних матеріалів, розміщує їх на Moodle та Вікі порталі. Існує спеціальна сторінка на сайті Університету, на якій розміщується опис нових інструментів з описом їх функціоналу.

B PHDPU (P6) за цей напрям відповідає кафедра інформаційних технологій та моніторингу якості освіти.

B PTUSPU (P7) функціонують науково-методична комісія факультетів/інституту та навчально-методична рада університету, в повноваження яких входить розгляд питання впровадження інноваційних інструментів та технологій навчання в освітній процес Університету. Спеціального підрозділу немає.

B SUNPUU (P8) за впровадження IКТ відповідає відділ інформаційних технологій, науково-методичні комісії факультету та університету відповідають за впровадження інноваційних інструментів та технологій навчання.

B LTSNU (P9) усі підрозділи університету відповідають за впровадження інноваційних навчально-технологічних інструментів та оцінку їх результатів (до певної міри). Ми вважаємо, що спеціалізована установа не здатна оцінити всі результати. Для цього ми не маємо спеціального підрозділу.

\section{Репозиторії навчальних ресурсів}

B VSPNU (P1) ці матеріали містяться на платформі електронної бібліотеки університету. Репозитарій (http://lib.pu.if.ua:8080/) створено рішенням вченої ради VSPNU (P1) з метою концентрації результатів наукових досліджень та освітніх матеріалів у єдиному сховищі, задля підвищення рівня цитування публікацій науковців університету та поширення їх у середовищі світового науково-освітнього співтовариства. Спільнота університету має доступ не лише до науково-методичних праць викладачів, а й до таких платформ: електронні архіви України, Міжнародний рейтинг репозитаріїв WEBOMETRICS, Директорія архівів відкритого доступу (OpenDOAR), Реєстр архівів відкритого доступу (ROAR), Директорія журналів відкритого доступу (DOAJ), Каталог відкритого доступу наукових ресурсів (ROAD), Конфедерація репозитаріїв відкритого доступу (COAR) та ін. Викладачам, науковцям, аспірантам та студентам університету рекомендовано самоархівувати власні праці наукового, навчального, методичного чи дослідницького характеру відповідно до політики репозитарію щодо якості матеріалів. Електронні ресурси пропонують різноманітну навчально-наукову літературу, повнотекстові книги, фотографії, аудіо, відео, закордонні ресурси тощо. 


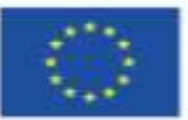

B BGKU (P5) (http://elibrary.kubg.edu.ua/), LTSNU (P9) (http://dspace.luguniv.edu.ua), PHDPU (P6) (http://ephsheir.PHDPU (P6).edu.ua:8081/xmlui/), $\quad$ PTUSPU (P7) (https://dspace.udpu.edu.ua/jspui//) існують репозиторіï.

Найбільший репозиторій підтримується в BGKU (P5) містить 16498 публікацій. Внутрішній репозиторій навчальних матеріалів, створений у 2009 р., містить 4815 матеріалів (доступний лише 3 внутрішньої мережі університету). Електронний каталог бібліотеки містить інформацію про ресурси, дозволяє шукати літературу за автором, назвою, дисципліною, темою, роком тощо. Адаптовані інструкції з використання е-ресурсів розміщені на сайті http://cikt.kubg.edu.ua.

\section{III ОПИС ПРОГРАМИ ТА НАВЧАЛЬНА ПРАКТИКА}

\section{Опис результатів навчання в освітніх програмах}

В університетах визначаються та описуються результати навчання для кожного курсу.

B VSPNU (P1) в освітніх програмах описано результати навчання, а також кожна освітня та робоча програми навчальної дисципліни містять критерії оцінювання навчальних досягнень здобувачів вищої освіти, форми і методи контролю, згідно вимог до навчальнометодичного комплексу навчальних дисциплін в усіх університетах. Усі робочі програми розміщені на сторінках відповідних кафедр, що забезпечують їх викладання. Навчальні плани та навчальне навантаження викладачів університету також міститься на спеціальній електронній платформі університету.

B BGKU (P5) результати навчання зазначаються у кожній робочій програмі навчальної дисципліни та відповідно до кожної спеціальності (спеціалізації), яку розробляють викладачі. Усі робочі програми публікуються на сторінках структурних підрозділів, розміщуються в інституційному репозиторії. Список затверджених навчальних планів відображається в peєстрі діяльності Univision. У той же час, в кожному ЕНК системи електронного навчання університету описуються результати навчання, компетентності та їх вимірювання. Відповідно до оформлення в ЕНК лабораторних, практичних та семінарських занять обов'язковою частиною $є$ критерії оцінювання для кожної діяльності (Положення про електронні навчальні курси: порядок створення, сертифікації та використання у системі енавчання). Кожна робоча програма містить критерії оцінювання досягнень студентів. Відповідно, перевірка доступності результатів вивчення дисципліни грунтується на успіху студентів. Остаточний контроль знань студентів відбувається за участю іншого викладача, як незалежного експерта.

B PHDPU (P6) освітні програми передбачають розробку компетентностей (інтегральних, загальних та професійних), визначаються та описуються результати навчання, а також їх поетапна адаптація на практичних заняттях та в ході практичної підготовки.

B PTUSPU (P7) в освітніх програмах визначені програмні результати підготовки фахівців відповідних спеціальностей та передбачено формування загальних та фахових компетентностей. Результати навчання визначені у навчальних та робочих програмах 


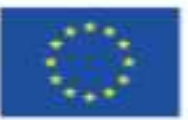

навчальних дисциплін. Кожна робоча програма містить критерії оцінювання досягнень студентів.

B LTSNU (P9) компетентності та показники їх вимірювання описані в освітній та робочих програмах. У всіх навчальних програмах $\epsilon$ опис результатів навчання. На практиці вони були перевірені за допомогою тестових та спеціальних завдань.

\section{Використання прикладів практичних досліджень та результатів наукових досліджень}

В VSPNU (P1) приклади реальних тематичних досліджень можуть бути експериментальними результатами навчальної практики, яку студенти можуть використовувати у своїх дослідженнях. Найбільш активними тут є факультет природничих наук (кафедра біохімії та біотехнологіi), фізико-технічний факультет (кафедра матеріалознавства і новітніх технологій, кафедра комп'ютерної інженерії та електроніки). Щороку студенти університету є переможцями Всеукраїнських конкурсів наукових робіт та олімпіад з різних напрямів STEAM-підготовки. Студенти також беруть участь в наукових звітних конференціях, які регулярно проводяться різними підрозділами університету, результати публікуються в електронних збірниках робіт конференцій. Наприклад, на педагогічному факультеті традиційно проводиться щорічна наукова Інтернет-конференція для студентів і молодих учених “Розвиток особистості молодших школярів" за участі студентів з інших країн.

BGKU (Р5) приділяє увагу використанню реальних прикладів та результатів наукових досліджень. Університет відображає результати наукової роботи викладача на веб-сайті факультетів, е-портфоліо. Роботи та опис реальних досліджень містяться в інституційному репозиторії. Студенти мають можливість використовувати науково-метричні бази даних, де представлені останні дослідження в різних галузях. Зокрема, студенти мають доступ до «Представлення результатів наукових досліджень магістрів 3 використанням ІКТ», де вони можуть ознайомитися 3 електронним середовищем університету та можливостями використання досліджень у своїй роботі. Студенти також беруть участь в конференціях, які регулярно проводяться різними підрозділами університету, результати публікуються в електронних збірниках робіт конференцій. Наприклад, на кафедрі комп’ютерних наук i математики (стара назва - інформаційних технологій та математичних дисциплін) проводяться конференції, результати яких можна переглянути за адресою: http://fitu.kubg.edu.ua/naukova-diialnist-kafedry/2-uncategorised/157-konferentsii-kafedryinformatsiinykh-tekhnolohii-i-matematychnykh-dystsyplin.html Студенти також беруть участь у всеукраїнських конкурсах наукових робіт студентів, де посідають призові місця (зокрема, http://fitu.kubg.edu.ua/pro-

fakultet/news/podiji/706-vitaiemo-peremozhnytsiu-ii-turu-vseukrainskoho-konkursu-studentskykhnaukovykh-robit-z-haluzi-znan-spetsialnostei-matematyka-ta-statystyka-prykladna-matematykamekhanika.html) та всеукраїнських студентських олімпіадах (зокрема, 
http://fitu.kubg.edu.ua/pro-fakultet/news/podiji/680-vitaiemo-peremozhnytsiu-vseukrainskoistudentskoi-olimpiady-zi-spetsialnosti-profesiina-osvita.html).

B PHDPU (P6) приділяється увага використанню предметного вивчення ситуацій 3 реального життя (реальні практичні приклади) та результатів наукових досліджень. Університет звертає увагу на використання у навчальному процесі проблемних технологій (case метод, метод аналізу конкретних ситуацій тощо), заснований на методах дослідження навчально-пізнавальної діяльності. 3 цього випливає важлива для навчання ознака: вміння використання попереднього досвіду у нових ситуаціях, а також поглиблення зв'язку між теорією і практикою. Студенти маю доступ до інформації на веб-сайтах та електронних портфелів, знайомляться 3 електронним середовищем університету 3 подальшим використанням інформації в наукових дослідженнях.

B PTUSPU (P7) приділяється значна увага впровадженню в освітній процес результатів прикладних наукових досліджень, зокрема викладачів Університету. Тематика наукових досліджень студентів відповідає держбюджетним та загальнокафедральним темам, що виконуються на кафедрах Університету. Результати наукових досліджень студентів висвітлюються у курсових та кваліфікаційних роботах, матеріалах конференцій різних рівнів та оприлюднюються на Всеукраїнських конкурсах наукових робіт.

B SUNPUU (P8) на навчальних курсах, результати наукових досліджень кафедр використовуються для розширення світогляду студентів. Студенти виконують індивідуальні прикладні наукові завдання.

В LTSNU (Р9) використовуються реальні приклади та результати досліджень. Можливі форми: проєктні та курсові роботи, теми дослідження протягом усього періоду навчання тощо.

\section{Форми інноваційних методів та технологій навчання у навчальних програмах}

У VSPNU (P1) дистанційне навчання використовується всіма викладачами університету; змішане навчання, проєктна діяльність, групова та парна навчальна діяльність, інтерактивна взаємодія, форми електронного навчання та інші використовуються за бажанням.

B BGKU (P5) навчальні програми регулярно оновлюються завдяки включенню нових освітніх технологій: за допомогою зовнішніх онлайнових курсів (МООС) в якості одного 3 компонентів цієї дисципліни, заміна стандартних практичних вправ для реалізації науководослідних проєктів студентів з можливістю розвитку підприємницьких навичок тощо. Це особливо чітко видно у навчальному плані щодо підготовки менеджерів електронного навчання та, відповідно, у програмі, дисциплін, які викладаються в спеціалізації. Навчання та навчання грунтуються на принципах студенто-центрованості та індивідуально-особистого підходу; реалізуються шляхом навчання на основі досліджень, зміцнення практичної орієнтації, білінгової підготовки. Існує три формати навчання (peer-to-peer, гібридного, 
онлайнового). Впроваджуються технології «перевернутого класу», взаємооцінювання, методу проєктів, робота в парах та групах.

B PHDPU (P6) програми визначають дидактичні форми навчання інновацій та інструменти. Технологічні інструменти реалізуються, зокрема, за допомогою досліджень на основі пошуків, посилення практичної орієнтації, білінгової підготовки. Існують такі формати навчання (F2F, hybrid, он-лайн). Впроваджені технології «інвертованого класу». Вводиться активність в парі та групах.

B PTUSPU (P7) у навчальних програмах зазначаються форми, методи та технології інноваційного навчання. Найбільш поширеними у використанні є: змішане навчання, мобільне навчання, інтерактивне навчання, електронне навчання, тощо.

B SUNPUU (P8) - змішане навчання.

B LTSNU (P9) програма містить опис навчальних методів та педагогічних технологій, що використовуються в курсі. Наприклад: курс використовує метод проєкту та технології пізнавального розвитку.

\section{Підтримка кафедри при перегляді навчальних програм}

B VSPNU (P1) кафедри та факультети отримують консультаційну підтримку від навчально-методичного відділу університету. Нові освітні програми відкриваються за потреби згідно існуючих вимог.

BGKU (P5) розробляє нові напрямки та спеціальності, залучає провідних спеціалістів, розробляє нові навчальні плани. Зокрема, у цьому навчальному році відкрита нова спеціалізація "Internet of Things", спеціальності "Кібербезпека", “Управління електронним навчанням”. Щороку всі навчальні програми обговорюються на засіданнях кафедр, розглядаються на Вченій раді університету, затверджуються проректором 3 науковометодичної та навчальної роботи та завівачем кафедри. Відповідно до змін у програмі, вносяться зміни до електронних курсів або створюються нові.

B PHDPU (P6) навчально-методична рада університету проводить організаційнометодичні консультації з розробки освітніх програм, полегшує їх обстеження та затверджує засідання Вченої ради університету.

B PTUSPU (P7) кафедри факультетів/інституту отримують належну підтримку у вигляді консультацій, семінарів та круглих столів щодо розробки та удосконалення освітніх програм, які затверджуються вченою радою університету.

B SUNPUU (P8)проведено науково-методичні семінари різних напрямків для вдосконалення навчальних програм.

У LTSNU (Р9) перегляд навчальних програм відбувається раз на 3-5 років (університетські норми).

\section{Структура навчальної програми}

У VSPNU (P1), BGKU (P5), PHDPU (P6), PTUSPU (P7) затверджено шаблон навчальної програми науково-методичною радою університету: 
Складовою частиною навчальної програми є:

- Титульна сторінка.

- Опис дисципліни.

- Мета та завдання навчальної дисципліни.

- Результати навчання за дисципліною.

- Структура навчальної дисципліни.

- Програма навчальної програми.

- Контроль навчальних досягнень.

- Навчально-методична картка дисципліни (модуль).

- Рекомендовані джерела.

- Додаткові ресурси.

Мультидисциплінарні дисципліни побудовані за модульною структурою.

B VSPNU (P1) кожен викладач має академічну свободу у розробці курсу відповідно до визначених компетентностей.

У BGKU (P5) це знайшло своє відображення в методичних рекомендаціях розробки робочих програм (http://kubg.edu.ua/images/stories/Departaments/vdd/documenty/rozdil_10/nakaz_359_25.05.2018. pdf), затверджених Вченою радою університету.

B PHDPU (P6) структура навчального плану передбачає нормативні дисципліни до 75\% та вибіркові навчальні дисципліни 3 25\% загальної кількості дисциплін. Мультидисциплінарність та гнучкість курсів підтримується вибірковим модулем навчальних дисциплін, спрямованих на реалізацію стратегії інтернаціоналізації, міжнародної академічної мобільності студентів шляхом гармонізації навчальних програм.

B PTUSPU (P7) всі мультидисциплінарні дисципліни мають модульну структуру. Структура всіх навчальних планів підготовки майбутніх фахівців передбачає 75\% нормативних (обов'язкових) дисциплін та 25\% дисциплін вільного вибору студента.

B SUNPUU (P8) програма представлена модульною структурою. Не менше 25\% навчальних програм має змінні компоненти для підтримки міждисциплінарності та гнучкості курсу.

В LTSNU (Р9) загальні курси, спеціальні курси, факультативні курси, використовуються міждисциплінарні факультативні курси (декілька підрозділів розробляють різні модулі курсу).

\section{Курси або навчальні модулі, інтегровані в навчальний план, під час яких обговорюється тема «Технології дистанційної освіти»}

B VSPNU (P1) питання сутності та вимог щодо організації дистанційного навчання $\epsilon$ предметом вивчення та часткового обговорення у процесі викладання педагогічних дисциплін «Дидактика», «Педагогічна інноватика», «Основи інклюзивної освіти». Студенти, які навчаються за індивідуальним графіком мають право обирати форми навчання - 
традиційні з елементами дистанційного навчання. Інші студенти можуть вивчати додатково матеріал, який пропонується онлайн, за бажанням.

B BGKU (P5) тема «Дистанційні технології навчання» обговорюються на курсах для спеціалізації «Управління електронним навчанням» в магістерських програмах спеціальностей: Початкова освіта, Дошкільна освіта, Педагогіка вищої школи; для «Управління електронним навчанням у міжкультурному просторі».

B PHDPU (P6) - впроваджується курс «Сучасні інформаційні технології», який викладається для студентів усіх спеціальностей на другому (магістерському) рівні й передбачає розгляд теми «Технології дистанційної освіти».

В PTUSPU (P7) розроблено курс «Основи дистанційної освіти в початковій школі» (90 годин).

B SUNPUU (P8) існує університетський курс «Технології дистанційної освіти».

B LTSNU (P9) - для цього є навчальний курс «Пропедевтика та IКТ» і один курс MOOC.

\section{Використання відкритих освітніх ресурсів у курсах}

B VSPNU (P1) відкриті освітні ресурси використовують на факультеті математики та інформатики, факультеті природничих наук. Однак це не $\epsilon$ обов'язковою вимогою щодо опанування навчальної дисципліни. Здебільшого відкриті освітні ресурси використовують у процесі самостійної роботи студентів.

B BGKU (P5) робочі програми передбачають закінчення онлайн-курсів (МООС, Prometheus, Coursera). Студенти також відвідують курси Академії Сisco. Отримані сертифікати враховуються як виконання певних завдань за дисципліною. Наприклад, при вивченні студентами програмування спеціальністю «Комп'ютерні науки» - це можливість пройти наступні MOOC: CS50, HTMLAcademy, Основи розробки веб-інтерфейсу тощо. Відповідно до певної галузі завершення онлайн-курсів можна зарахувати як модульні контрольні роботи, самостійне вивчення одного модуля або певної лабораторної роботи.

В PHDPU (P6) у викладанні використовуються відкриті навчальні ресурси: Репозиторій - загальнодоступний ресурс в Інтернеті, що містить вибір програмних пакетів 3 piзних тем. Moodle (Модульне об'єктно-орієнтоване динамічне навчальне середовище) - це модульне об'єктно-орієнтоване динамічне навчальне середовище, яке надає вчителям, студентам та адміністраторам ширше застосування набору інструментів електронного навчання, включаючи віддалене.

B PTUSPU (P7) - на персональних сайтах викладачів.

B SUNPUU (P8) Відкриті освітні ресурси використовуються в курсах як частина самостійної роботи студентів.

B LTSNU (P9) курси включають посилання. 


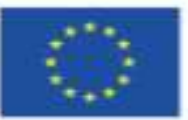

\section{Освітні ресурси з ліцензісю Creative Commons}

B VSPNU (P1) - елементи таких ресурсів перебувають під експериментом деяких викладачів, які ще не опубліковані як відкриті освітні ресурси за ліцензією Creative Commons.

B BGKU (P5) - викладачі та студенти створюють і заповнюють різноманітні е-ресурси (блоги, карти знань, онлайн-презентації, Prezi, Kahoot, Socrative, educational videos, wiki Coggle - Презентація- Prezi - Спільний студентський блог.

B PTUSPU (P7) використовують масові он-лайн курси Prometeus для підвищення кваліфікацій викладачів та підготовки студентів.

B PHDPU (P6), SUNPUU (P8)- такі курси не використовуються.

B LTSNU (Р9) - існують курси МOOC для абітурієнтів.

\section{Забезпечення інтерактивної взаємодії}

B VSPNU (P1) інтерактивна взаємодія передбачає діалогове навчання, вирішення майбутніми вчителями проблемних ситуацій шкільної практики, групову чи парну активність з обговорення сучасних кінофільмів на педагогічну тему (в т.ч. зарубіжних), телепередач, рольових (ділових) ігор для розвитку критичного мислення, формування та розвитку професійних компетентностей з використанням комп’ютерних технологій. Також в університеті часто організовують вебінари та онлайн-конференції між студентами i викладачами різних університетів з обговорення актуальних педагогічних проблем.

B BGKU (P5) - використовуються для взаємооцінювання:

- Ресурс «семінар» на LMS Moodle;

- додатки Google;

- блоги;

- інтерактивні дошки (Padlet тощо).

Наприклад, ці методи та інструменти використовуються в курсах «Методика навчання інформатики», «Соціальні медіа в електронному навчанні», «Оцінювання в умовах електронного навчання» як частину завдань для лабораторних чи семінарських занять.

B PHDPU (P6) навчальний план передбачає організацію самостійної роботи студентів у розмірі 50\% загальної суми кредитів. Оцінка діяльності студентів у виконанні завдань модуля самостійної роботи проводиться, зокрема, в режимі онлайн (робота в навчальному модульному середовищі 3 використанням IКТ). Для студентів дистанційного навчання використовуються елементи дистанційної освіти (перевірка якості освоєння модулів теоретичного рівня знань та самостійної роботи). Всі студенти мають можливість отримати пораду щодо написання проєктів та проведення наукової роботи дистанційно. (Положення про порядок та методологію оцінки знань студентів у умовах кредитно-модульної системи організації навчального процесу).

B PTUSPU (P7) існує досвід організації міжвідомчих вебінарів та он-лайн-конференцій між закладами вищої освіти. 


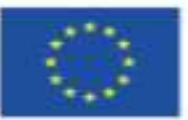

B LTSNU (P9) використовується методика peer to peer за допомогою ресурсу Moodle «семінар».

\section{Навчальний курс для навчання інтегрованій освіті}

B VSPNU (P1) є курси, які викладаються для студентів різних факультетів (наприклад, “Основи педагогіки”, “Основи наукових досліджень”).

BGKU (P5) координує альтернативну узгоджену загальнонаціональну програму «Початкова школа: освіта для життя», яка включає в себе інтеграцію семи предметів школи (включаючи інформаційну грамотність). В рамках експерименту «Розробка та впровадження електронних освітніх ресурсів» на базі університету проводяться тренінги для вчителів початкової школи з використання інструментів інтегрованого навчання.

B PTUSPU (P7) розроблено та впроваджено курси «Методика навчання природничонаукових дисциплін», яка включає в себе методику викладання фізики, хімії, біології, природничих наук; “Методика навчання освітньої галузі “Мистецтво”", що включає методику навчання музичного мистецтва та методику навчання образотворчого мистецтва; “Методика навчання освітньої галузі “Технології”” (трудове навчання та інформаційнокомунікаційні технології).

B SUNPUU (P8) існує курс для навчання інтегрованій освіти у середній та профільній школі.

B LTSNU (P9) та PHDPU (P6) таких курсів немає.

\section{Навчання студентів soft skills та рівень їх сформованості}

B VSPNU (P1) існує освітня програма для підготовки фахівців (тут визначаються soft i hard skills, і там наведені назви курсів).

B BGKU (P5) є загальне бачення щодо формування у студентів soft skills, але немає спеціального курсу для навчання soft skills. Сучасні навчальні аудиторії обладнані меблямитрансформерами для організації спільної роботи за круглим столом. Університет запровадив стандарти IК-компетентностей магістрів та викладачів, що включає у тому числі й soft skills. Вимоги до ЕНК, які розробляються викладачами для різних дисциплін, включають різноманітні види діяльності, такі як спільна діяльність студентів, співпраця та спілкування, використання різноманітних інструментів, такі як форуми, чати, онлайнове взаємооцінювання тощо. Відповідно до нової освітньої стратегії, кількість навчальних програм було скорочено у навчальних планах, але кількість практик було збільшено. Студенти проходять окремі курси та тренінги з лідерства, для першокурсників запроваджено дисципліну «Я - студент». Концептуально в кожному предметі передбачається формування soft skills. В Університеті в рамках проєкту «Стартап без кордонів» створені Інкубатори, організовано зустрічі щодо можливості створення власного глобального стартапу в Україні, презентовано приклади успішних вітчизняних стартапів, розкрито сутність та значення інкубаторів в екосистемі стартапів України. 


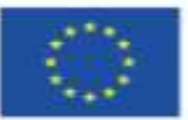

B PHDPU (P6) створено Положення про порядок та умови організації вивчення обраних дисциплін навчального плану спеціальності підготовки фахівців ДВНЗ «ПереяславХмельницький державний педагогічний університет імені Григорія Сковороди».

Це передбачає формування цивільних, соціальних, мультикультурних та ін. компетентностей, які полегшують набуття гнучких навичок студентами.

B PTUSPU (P7) немає окремого навчального курсу, який передбачає формування у студентів суто soft skills, але переважна більшість навчальних дисциплін передбачає формування окремих soft skills у студентів.

B SUNPUU (P8) існує частина списку компетентностей, без оцінювання.

B LTSNU (P9) розроблено «Пропедевтика та IКТ». Курс включає навички критичного мислення, цифрової грамотності, навичок навчання, спілкування.

\section{Навчання студентів критичному мисленню}

B VSPNU (P1) не розроблена спеціальна методологія для розвитку критичного мислення студентів, однак викладачі використовують різноманітні методи та форми роботи для практичного вирішення цього завдання у контексті викладання дисциплін гуманітарного та природничо-математичного циклу.

B BGKU (P5) спеціальна методика викладання критичного мислення у студентів відсутня. Концептуально в кожному предметі передбачається формування критичного мислення, як складової soft skills.

В PHDPU (P6) здійснюється випробування ефективності методології навичок критичного мислення у студентів на стадії експериментального дослідження.

B PTUSPU (P7) немає спеціальних курсів для розвитку критичного мислення, проте технології та методи формування критичного мислення присутні у кожній дисципліні.

B SUNPUU (P8) існують оригінальні комп'ютерні тести, розроблені кафедрою інноваційних методів навчання та методів викладання природних дисциплін.

B LTSNU (Р9) передбачається вирішення проблемних ситуацій, проблемних завдань, аналітичних карт, групова робота тощо.

\section{IV СПІЛЬНОТИ. ГРОМАДСЬКА ПОЗИЦІЯ}

\section{Активні навчальні спільноти студентів}

У VSPNU (P1) студенти беруть участь в освітньому процесі університету, в т.ч. обирають навчальні дисципліни (25\%). Вони активні у кількох навчальних спільнотах, мають свободу вибору. Вони можуть звертатися до університетської адміністрації та місцевої влади, якщо цього потребують, у них є багато можливостей.

B BGKU (P5) студенти активно беруть участь у прийнятті рішень щодо організації освітнього процесу. Студенти мають можливість вибору дисциплін не менше $25 \%$ загальної кількості кредитів. Їхні думки та бачення збираються за допомогою анкет: оцінювання ЕНК, 
оцінювання діяльності викладача та рефлексій. Результати використовуються викладачами для покращення ресурсів, формують рейтинг викладачів, враховуються у Е-портфоліо викладача, в яке додаються результати оцінювання студентами навчальних ресурсів ЕНК після завершення вивчення дисципліни; щорічного опитування «Викладач очима студентів» щодо оцінювання якості викладання. Проводиться анкетування задоволення студентамипершокурсниками навчальним середовищем Університету.

B PHDPU (P6) студентська рада, наукове студентське товариство беруть активну участь у формуванні навчального середовища. Думки студентів приймаються до уваги адміністрацією університету.

B PTUSPU (P7) функціонують студентська рада, студентське наукове товариство, які беруть активну участь в освітньому процесі, свої зауваження та пропозиції висловлюють під час анкетування щодо покращення процесу навчання. Крім того, діють Центр родинного виховання, Молодіжний центр «Старт», Гендерний центр, Центр психологічного тестування та тренінгових технологій «Insait», національно-патріотичний табір для студентської молоді «Дія», соціально-психологічна служба, Центр соціально-освітньої інтеграції та інклюзивного туризму «Без бар'єрів».

B SUNPUU (P8) студенти можуть створювати свої навчальні спільноти як частину соціальних мереж.

В LTSNU (P9) студенти беруть участь у формуванні навчального середовища 3 допомогою відгуків про навчальні курси. Думки студентів аналізуються навчальним відділом та студентським самоврядуванням. Університет проводить вибіркові опитування студентів (lime.luguniv.edu.ua):

- загальна оцінка роботи університету, задоволення;

- оцінка вчителя;

- оцінка навчального матеріалу;

- оцінка навчальних ресурсів;

- оцінка курсів.

\section{Обмін найкращими практиками серед викладачів}

У VSPNU (P1) існує багато можливостей для цього. Наприклад: семінари, майстеркласи, періодичні публікації, міжнародні стажування, онлайн конференції тощо. На рівні кафедр університету організовано співпрацю щодо обміну досвідом діяльності викладачів, вивчення кращих практик фахової підготовки. Для підвищення професійної майстерності та фахової кваліфікації викладачі проходять наукові стажування на споріднених кафедрах інших закладів вищої освіти як в Україні так і за ії межами. На кафедрах організовуються науково-методичні семінари, проводяться відкриті лекції, які обговорюються колегами.

BGKU (P5) організує та проводить семінари, тренінги, майстер-класи, конференції різних рівнів: кафедральні, факультетські, інститутські, загальноуніверситетські, міські, всеукраїнські та міжнародні. При цьому колеги знайомляться із результатами навчання та 
стажування в інших закладах освіти, у тому числі й закордонних. Проводять презентації власних публікацій, авторських методик тощо.

B PHDPU (P6) відбувається проведення міжнародних та всеукраїнських конференцій, круглих столів, семінарів, тренінгів, майстер-класів, відкритих лекцій з метою обміну, популяризації та поширення інноваційного досвіду.

B PTUSPU (P7) проходять семінари для керівників відділів, наукових і педагогічних працівників 3 досвідом роботи понад 5 років, школа молодого викладача, проведення відкритих занять викладачів, взаємовідвідування, шевство над молодими викладачами.

B SUNPUU (P8) організуються семінари, відкриті лекції, консультації.

\section{Різноманітність студентів та врахування їх в освітньому процесі}

VSPNU (P1) має студентське самоврядування. Деякий відсоток студентів вступає до вчених рад інститутів та факультетів. Організована діяльність студентського Сенату, зокрема активно працює в університеті студентський простір «Параграф» тощо.

Інша організація - студентський парламент складається з представників студентів всіх факультетів. Основними завданнями студентського парламенту є:

- забезпечення та захист прав та інтересів студентів, зокрема щодо організації навчального процесу;

- забезпечення виконання студентами своїх обов'язків;

- сприяння навчальній, науковій та творчій діяльності студентів;

- сприяння створенню належних умов для проживання та відпочинку студентів;

- сприяння діяльності студентських клубів, товариств, об'єднань, клубів інтересів;

- організація співпраці з учнями інших вищих навчальних закладів та молодіжних організацій;

- сприяння зайнятості випускників;

- участь у вирішенні міжнародних проблем студентського обміну;

- сприяння проведенню соціологічних досліджень серед студентів.

BGKU (P5) орієнтований на студента та сповідує принцип студентоцентризму. Головним органом студентського самоврядування $є$ Конференція студентів Університету. Студенти організували Студентський парламент, обрали його керівництво, розподілили обов'язки. Комітет культури та дозвілля займається організацією дозвілля студентів. Соціально-волонтерський комітет спрямовує діяльність на надання безкорисливої допомоги. Інформаційний комітет повідомляе про новини в офіційних групах Студентського парламенту, на сторінках соціальних мереж, займається наповненням офіційної сторінки СП на порталі Університету, займається популяризацією бренду Університету, здобутків науково-дослідної діяльності студентів, виконання навчальних проєктів. BGKU (P5) запрошує до навчання іноземних студентів. Приміщення університету адаптовані для користування студентів з особливими потребами ліфтами та пандусами.

B PHDPU (P6) студентська рада, наукове студентське товариство беруть активну участь у формуванні навчального середовища. Думки студентів приймаються до уваги адміністрацією університету. 


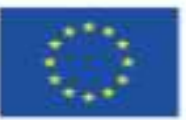

B PTUSPU (P7) функціонує студентське самоврядування, члени якого входять до вчених рад факультетів/інституту та університету. Студентське самоврядування бере активну участь в організації, функціонуванні та контролі освітнього процесу.

B SUNPUU (P8) - студенти можуть створювати свої навчальні спільноти як частину соціальних мереж.

В LTSNU (P9) студенти беруть участь у формуванні навчального середовища 3 допомогою відгуку про курси. Думки студентів аналізуються навчальним відділом та студентським самоврядуванням. Університет проводить вибіркові опитування студентів (lime.luguniv.edu.ua):

- загальна оцінка роботи університету, задоволення;

- оцінка вчителя;

- оцінка навчального матеріалу;

- оцінка навчальних ресурсів;

- оцінка курсів.

\section{Залучення студентів до науково-дослідних просктів}

У VSPNU (P1) студенти беруть участь у міжнародних конкурсах наукових дослідженнях, студентських конференціях, програмах обміну, існує можливість навчання на освітньому рівні “Магістр” за програмами подвійних дипломів з польськими університетами. Навчання у польських університетах відбувається на підставі двосторонніх угод паралельно 3 навчанням у магістратурі Прикарпатського університету за 12-ма спеціальностями: 104 Фізика та астрономія, 111 Математика, 113 Прикладна математика, 014.09 Інформатика, 013 Початкова освіта, 242 Туризм, 033 Філософія, 103 Науки про землю, 032 Археологія, 052 Політологія, 055 Міжнародні відносини, суспільні комунікації та регіональні студії, 017 Фізична культура і спорт, 112 Статистика, 081 Право.

Всі види науково-дослідницької діяльності оцінюються на рівні конкурсу, а студенти отримують додаткові стипендії та інші винагороди. На кожній кафедрі організована науководослідна робота зі студентами. Працюють наукові гуртки, проблемні наукові групи. Результати своїх досліджень студенти мають можливість представляти на наукових форумах різного рівня (наприклад, участь магістрантів та студентів кафедри інформатики у щорічній міжнародній науковій конференції «Студентське коло наукове» у Гірничо-металургійній академії імені Станіслава Сташиця, Краків, Республіка Польща). В VSPNU (P1) традиційно видруковуються збірники студентських наукових робіт за профілем кафедри, зокрема: «Студентські історичні зошити», «Політологічні студії. Студентський науковий вісник». Для кращих студентських статей існує загальноноуніверситетський міждисциплінарний збірник «Еврика» 3 проблем математики, фізики, хімії, біології, екології, економіки, історії, філософії, політології, релігієзнавства, культурології, філології, педагогіки, мистецтвознавства, туризму, фізичного виховання і спорту за підсумками звітної наукової конференції студентів університету за кожен рік.

В BGKU (Р5) відбувається залучення студентів до науково-дослідних проєктів, популяризування науки в університеті: створено наукове товариство студентів, аспірантів, 
докторів та молодих вчених. Науковий фестиваль в Київському університеті імені Бориса Грінченка проводиться вже 4 роки поспіль. На сайті електронного журналу «Наукові доробки магістрантів» опубліковано наукові статті студентів Київського університету імені Бориса Грінченка, щорічно проводяться студентські наукові конференції та семінари, всеукраїнський конкурс студентських наукових робіт.

В PHDPU (P6) здійснюється залучення студентів до наукового дослідження проводиться через організацію роботи студентського наукового товариства. Використовується системний підхід до роботи над проєктом. Основними критеріями ідеї для проєкту $€$ актуальність, новаторська новизна, прикладне значення. Проєктний метод впроваджується $з$ першого року навчання студентів при вивченні курсу «Основи наукових досліджень».

В PTUSPU (P7) здійснюється залучення студентів до дослідницьких проєктів в позааудиторний час, переважно під час роботи в науковому товаристві та виконання індивідуальних дослідницьких завдань, які оцінюються за відповідною шкалою зазначеною у навчальній програмі відповідної дисципліни, участь студентів у міжнародних та всеукраїнських конкурсах та олімпіадах, науково-практичних конференціях різних рівнів. Залучення студентів до роботи у студентських наукових гуртках та проблемних групах, зокрема, наукового гуртка “Технологія організації освітнього простору” при Польськоукраїнській науково-дослідницькій лабораторії психодидактики імені Я.А. Коменського.

B SUNPUU (P8) студенти беруть участь у дослідницьких проєктах як технічний персонал.

B LTSNU (P9) починаючи з другого курсу студенти обирають тему для дослідження. Вона стає основою для написання курсових та інших письмових робіт, творчих завдань курсів та додаткової наукової роботи.

\section{V ТЕХНОЛОГІЧНІ ПИТАННЯ}

\section{Впровадження інноваційних методів та освітніх технологій}

У VSPNU (P1) функціонує відкрита лінія з ректором, система «Наука» (для оформлення звітів про науково-дослідну роботу усіх працівників університету за роками), «Кадри» (для обліку всіх працівників університету), система документообігу «DEKANAT», е-розклад для студентів, перевірка дипломних робіт на плагіат, електронна бібліотека, а також у навчальнометодичному відділі розроблено навчальне навантаження для викладачів відповідно до навчальних планів на е-платформі університету. Електронна платформа для дистанційного навчання на базі EduPRO (для роботи з сайтом рекомендується використовувати один 3 браузерів, Mozilla Firefox, Google Chrome або інші), комп'ютерні класи, мультимедійні аудиторії.

B BGKU (P5) система електронного навчання впроваджена у всьому університеті та організована на платформі LMS Moodle 3 розробленим додатковим модулем е-деканату; використовуються інші інструменти: система перевірки на плагіат магістерських та 
бакалаврських робіт (власна розробка), експертиза плагіату книг, посібників, дисертацій; віртуальна гібридна лабораторія Goldi, існує університетський канал YouTube. Створено модуль «Статистичні дані» щодо функціонування системи е-навчання (активність викладачів та студентів у ЕНК, оцінювання) та окремий ресурс е-портфоліо.

PHDPU (P6) використовує автоматизовану систему управління на базі 1C: підприємства 8, завдяки якій здійснюється управління освітньою, науково-педагогічною роботою, обліком навчально-виховного навантаження вчителів, його впровадженням, моніторингом якості знань студентів, оцінкою успішності бакалаврів , магістри, самостійна робота в модульному середовищі студентів денної та заочної форми навчання; Moodle платформа для електронного навчання; мультимедійні класи

B PTUSPU (P7) існує система Anti-Plagiarism, платформа для вебінарів, система моніторингу освітньої та пізнавальної діяльності на платформі Moodle.

B SUNPUU (Р8)використовується BigBlueButton для проведення вебінарів. Система AntiPlagiat для перевірки всіх видів результатів студентів та викладачів. MS Azure використовується для навчання студентів співпраці та як хмарне сховище. Університет планує запровадити автоматизовану систему управління.

B LTSNU (P9) використовується LMS Moodle, ЛНУ.УКР (Гібридний електронний університет).

\section{Підтримка адміністрації університету з питань розширення інфраструктури електронного навчання}

В VSPNU (P1) існує відділ інформаційних технологій, який відповідає за впровадження, використання та розширення інфраструктури електронного навчання.

В BGKU (P5) здійснюється підтримка адміністрацією Університету впровадження та використання інфраструктури електронного навчання:

1. Правова база даних включає в себе необхідні накази та положення (див. А.ІІ.2)

2. Однією з умов отримання звання доцента або професора є наявність розробленого та сертифікованого ЕНК.

3. В е-портфоліо надаються високі бали за використання ЕНК.

4. Організація навчального процесу - положення передбачає, що всі дисципліни для студентів заочної форми навчання повинні обов'язково бути забезпечені ЕНК.

5. Закуплено обладнання (гарнітури та веб-камери) для кожного структурного підрозділу та проведено навчання викладачів щодо способів створення дидактичного відео.

6. У системі підвищення кваліфікації було створено окремий модуль для підготовки викладачів для створення власного електронного курсу.

7. Вчена рада університету прийняла та затвердила Стандарт цифрової компетенції викладача.

В PHDPU (P6) адміністрація університету поповнює і оновлює матеріально-технічні ресурси університету, стимулює i заохочує впровадження електронного навчання. Університет проводить курси «Інформаційні технології в освіті», в рамках яких викладачі 
навчають користуватися сучасними інформаційними технологіями в навчальному процесі, а також систему електронного навчання на базі платформи Moodle. Адміністрація університету мотивує вчителів впроваджувати та використовувати інфраструктуру електронного навчання. Так, однією $з$ умов отримання звання доцента або професора $є$ наявність розробленої та сертифікованої освітньої продукції 3 використанням мультимедійних технологій. Організація навчального процесу за допомогою Moodle передбачає, що студенти дистанційної форми навчання повинні обов'язково пройти всі дисципліни та скласти 3 модулі (теоретичної, практичної і самостійної підготовки). Адміністрація планує придбати обладнання для кожного навчального структурного підрозділу та організовує підготовку вчителів для створення дидактичного відео. Вчена рада університету вивчає документи для затвердження стандартів цифрової компетенції вчителя.

B PTUSPU (P7) функціонує інформаційно-обчислювальний центр, який забезпечує технічну підтримку електронного навчання та Центр дистанційного навчання, який надає консультаційну допомогу.

B SUNPUU (P8) створено центр інновацій, завданням якого $є$ розробка та впровадження концепції електронного навчання.

B LTSNU (P9) університет також має Центр інформаційних технологій, науковий центр забезпечення якості освіти та сектор дистанційного навчання. Адміністрація університету визначила розвиток цифрових та інноваційних технологій як стратегію розвитку університету.

\section{Підтримка процесів впровадження IКТ}

В VSPNU (P1) співробітники мають право вільно використовувати цифрову інфраструктуру (на підставі попереднього погодження або за розкладом).

B BGKU (P5) цифрова інфраструктура підтримує спеціальні методи навчання (багатосторонні класи) для студентів як LMS, EHК та MOOC.

B PHDPU (P6) мультимедійні кабінети - це приміщення, призначені для відображення аудіо та візуальної інформації, оснащеної проекційною системою або великими діагональними телевізійними екранами, а також системою озвучення.

B PTUSPU (P7) факультети/інститут мають вільний доступ до використання цифрової інфраструктури для забезпечення ефективності навчального процесу, зокрема, впровадження комп'ютерно-орієнтованих технологій навчання, сертифікація електронних навчальних курсів розміщених у системі дистанційного навчання (Moodle).

B SUNPUU (P8) реалізація інноваційних технологій сприяє формуванню нового способу мислення та можливості використання інформаційних підходів

B LTSNU (Р9) тренінги з використанням IКТ проводяться в багатопрофільних класах. 


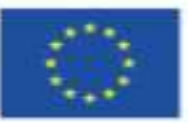

\section{Використання онлайн-середовища для підтримки навчальних курсів}

B VSPNU (P1) на окремих факультетах (філософський факультет, факультет математики та інформатики та ін.) використовують освітнє онлайн середовище Moodle та ClassRoom. Однак здебільшого - це власне бажання та інноваційність викладачів. Це розширює можливості самостійної роботи студентів, сприяє розвитку критичного мислення. У кожного викладача $є$ персональний код доступу до системи EDY PRO. Там вони можуть презентувати лекції, практичні завдання, тести, а також проводити онлайнові лекції, консультації тощо. Це практична база для дистанційного навчання студентів, яка більш інтенсивно використовується у зимово-весняний період.

B BGKU (P5) створено Е-середовище - система електронного навчання на базі LMS Moodle, Вiкi, інституційного та електронного репозиторіїв Київського університету імені Бориса Грінченка, корпоративний студентський акаунт, який дозволяє використовувати pecypcи Google Apps. Все це допомагає організувати підтримку та доступ до навчальних ресурсів 24/7/365; організовує діяльність та активне онлайн-навчання.

B PHDPU (P6) онлайн-середовище Moodle (Модульне об'єктно-орієнтоване динамічне навчальне середовище) надає педагогам, студентам та адміністраторам розширений набір інструментів електронного навчання, включаючи дистанційне навчання.

В PTUSPU (P7) підтримка навчальних курсів здійснюється на основі використання навчально-освітнього середовища Moodle та ClassRoom, які допомагають розглянути організаційні аспекти навчального курсу, забезпечує навчальними ресурсами, організовує діяльність та активне онлайн-навчання.

B SUNPUU (P8) онлайн-середовище забезпечує (підтримує) навчальні ресурси.

B LTSNU (Р9) вміст, завдання, тести, відео тощо на всіх курсах використовуються для підтримки онлайн-середовища.

\section{Основні інвестиції в цифрову інфраструктуру в останні кілька років}

VSPNU (P1) - Wi-Fi для студентів та академічних інструкторів безкоштовно, проектори, комп'ютери в аудиторіях (не достатня кількість). Крім того, за допомогою міжнародних проєктів Erasmus + були створені два потужних комп'ютерних класи (філософські та математичні факультети). Цифрова інфраструктура університету повинна постійно вдосконалюватися у розвитку цифрових технологій.

B BGKU (P5) оновлено парк комп'ютерної техніки, проведено якісну мережу в навчальних корпусах, створено лабораторію вбудованих систем, навчальний центр SMART.

B PHDPU (P6) інвестиціями в цифрову інфраструктуру університету стали: проектори, мультимедійні кімнати з відповідним обладнанням, зокрема, під час роботи над проєктами TEMPUS та EcoBRU.

B PTUSPU (P7) функціонують безкоштовні зони Wi-Fi для студентів та викладачів, ITлабораторії, мультимедійне забезпечення в лекційних класах.

B LTSNU (P9) в рамках співпраці з USAID встановлено 2 сервери. 


\section{Підтримка інформаційної безпеки}

B VSPNU (P1) в якості заходів ми можемо використати час для відновлення системи після збою. Вони не мають належного рівня конфіденційності та безпеки.

B BGKU (P5) в якості заходів безпеки можна зазначити досить стислий час, що використовується для відновлення системи «Е-середовище Університету» після збою. Система комплексної кібербезпеки університету розробляється відповідно до європейського стандарту.

B PHDPU (P6) у відповідності до Закону України «Про державну таємницю» та «Про захист інформації в автоматизованих системах» університет здійснює контролюючу функцію по забезпеченню захисту інформації у процесі іiі формування, пересилання, приймання, оброблення, відображення в автоматизованих системах, сприяє захисту відомостей, що складають державну, службову та комерційну таємницю.

В PTUSPU (P7) система зв'язку є безпечною та забезпечує відповідний рівень конфіденційності.

B SUNPUU (P8) відділ інформаційних технологій протягом однієї години здійснює відновлення системи після збою.

В LTSNU (Р9) використовується концепція 50 на 50.

\section{Розвиток стартапів та екосистеми в Університеті}

B VSPNU (P1) університетська команда стала переможцем міжнародного турніру 3 робототехніки (в 2015 року в Арені Львів відбулася виставка «Експеримент Ні-Тесh Ехро» унікальна для України виставка сучасних технологій та нових продуктів у галузі IT).

- Проєкт EC Tempus BUSEEG -RU-UA «Отримання професійних та ділових навичок за допомогою освітніх та консалтингових стартапів». («Acquiring professional and business skills through education and consulting start-ups»).

- «Жуйка на основі карамелізованого меду, воску та прополісу для профілактики та лікування пародонтиту і пародонтозу та інших стоматологічних захворювань» (проф. Сергій Курта, студентка Марта Цап).

- «Впровадження технологій мобільного навчання та доповненої реальності під час вивчення хімії в закладах середньої освіти» (доцент Лілія Мідак).

- Студентський простір «Параграф» тощо.

B BGKU (P5) створено студентський інкубатор стартапів, підписано меморандум про співпрацю з “ҮЕР!".

B PHDPU (P6) екосистема розробляється в рамках проєкту EcoBRU, метою якого є підвищення екологічної компетенції вчителів та виховання екологічної культури майбутніх фахівців.

В PTUSPU (P7) розвивається екосистема університету, діє бізнес-центр УдПУ, метою якого $є$ створення умов для інтеграції науки, освіти та бізнесу внаслідок реалізації 


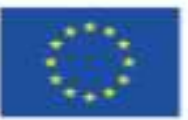

підприємницьких ідей студентів та викладачів університету, передачі результатів досліджень, а також розробка сучасних форм організації студентської наукової роботи.

B SUNPUU (P8) немає стартапів; розвивається екосистема університету.

B LTSNU (P9) немає стартапів. Планується розпочати роботу центру коворкінгу.

\section{Приклади трансформації освітнього процесу університету, які відбулися завдяки ефективному впровадженню IКT}

Студенти та викладачі VSPNU (P1) вивчають нові IКТ та вдосконалюють форми роботи 3 їх використанням (елементи змішаного навчання, мобільне навчання), збільшення годин для самостійної роботи студентів (зокрема заочної форми навчання) 3 використання IКТ (створення мультимедійних проєктів, відеофільмів, пошук навчальних фільмів на певну тему та ін.).

B BGKU (P5) запроваджено систему навчання студентів за принципом 50/50, тобто половина традиційних аудиторних занять проводиться в режимі онлайн або дистанційно. Студенти мають ЕНК, як е-підтримка для кожної дисципліни або повноцінні ЕНК для студентів заочної форми навчання. Студенти мають онлайн підтримку традиційних аудиторних занять за допомогою ЕНК.

B PHDPU (P6) структура IKT вищого навчального закладу ділиться на «галузеві» цілі:

- IКТ адміністративного спрямування (Програмний продукт «1С:Підприємство 8, Комплект для навчальних вищих i середніх закладів України» включає платформу «1С:Підприємство» версій 8.3, типові прикладні рішення);

- Інформаційно-комунікаційне педагогічне середовище (модульне об'єктно-орієнтоване динамічне навчальне середовище Moodle (Modular Object-Oriented Dynamic Learning Environment).

- Дистанційне навчання сприяє вільному запису на дистанційні навчальні курси, самостійному плануванню навчання. Використання Інтернет-технологій знімає територіальні обмеження і відкриває необмежені можливості участі в дистанційних заходах для всіх бажаючих.

- Віртуальна бібліотека. Використання ІКТ дозволяє значно поліпшити процес пошуку та одержання необхідного видання читачу електронної бібліотеки. Віртуальні бібліотеки надають своїм користувачам практично ті самі основні послуги, що і традиційні бібліотеки: доступ до каталогів бібліотеки з організацією пошуку та формування переліку замовлень; організація доступу до бібліотечного фонду, що представлений електронними аналогами різних видань (книг, журналів, газет та ін.).

- Веб-заняття - дистанційні пари, конференції, семінари, ділові ігри, лабораторні роботи, практикуми та інші форми навчальних занять, що проводяться за допомогою засобів телекомунікацій та інших можливостей Інтернет. Для проведення Веб-заняття використовуються спеціалізовані освітні Веб-форуми - форма роботи користувачів за певною темою або проблемою із допомогою записів, що залишаються на одному з сайтів, на якому встановлене відповідне програмне забезпечення. 
- Вебінари (семінари) - особливий тип Веб-конференцій, що допускають лише односторонній зв'язок між аудиторіями (мінімальний зворотний зв'язок від аудиторії). Зв'язок, як правило, односторонній - $з$ боку доповідача взаємодія із слухачами обмежена. Вебінари можуть бути сумісними і включати сеанси голосувань і доповідей, що забезпечує повну взаємодію між аудиторією і викладачем. Нині Вебінар використовують в межах системи дистанційного навчання.

PTUSPU (P7) - впровадження мобільних технологій, за допомогою яких студент може отримувати інформацію про навчання в будь-який час, незалежно від того, де він перебуває. Здійснюється змішане навчання, яке передбачає поєднання очних та он-лайн занять.

B SUNPUU (P8) самостійна робота студентів була оптимізована. Кількість аудиторних класів зменшилася на користь самостійної роботи.

LTSNU (P9) - перенесення (переїзд) університету в 2014 році відбулося за допомогою IKT.

\section{Е-портфоліо студента, викладача}

VSPNU (P1) немає е-портфоліо студента, але є персональна веб-сторінка та е-портфоліо академічних інструкторів на університетській платформі (http://www.d-learn.pu.if.ua/).

B BGKU (P5) впроваджується е-портфоліо студента, е-портфоліо викладачів . Для цього використовуються такі технології:

- Система е-портфоліо викладача

- Е-портфоліо викладача на WIKI платформі університету (https://goo.gl/uFuSF9).

- E-портфоліо студента на WIKI платформі університету(https://goo.gl/AjZARS).

PHDPU (P6) - на стадії формування.

B PTUSPU (P7), SUNPUU (P8), LTSNU (P9) - немає.

\section{Електронний кабінет викладача}

B VSPNU (P1) більшість академічних інструкторів мають лише власну веб-сторінку, але не мають власного електронного кабінету. Наявність такого електронного кабінету сприятиме підвищенню ефективності роботи викладацького складу, підвищенню рівня його взаємодії зі студентами. Однак на платформі дистанційної освіти кожен викладач має свою електронну сторінку (http://www.d-learn.pu.if.ua/), де завантажує власний освітній контент для студентів окремих груп та має можливість його вдосконалювати, доповнювати.

B BGKU (P5) власний електронний кабінет викладача реалізується яке «Персональний кабінет» - «Сторінка викладача», розроблені на платформі Moodle, що включають інформацію про навантаження викладача, перелік дисциплін та ЕНК, індивідуальний план тощо.

PHDPU (P6) - на стадії формування.

B LTSNU (Р9) академічні інструктори не мають власного електронного кабінету. 


\section{Використання електронного журналу та е-деканату}

У навчальному процесі VSPNU (P1) відсутні електронні журнали. Електронна платформа «DEKANAT» надає електронний реєстр груп. Він також використовується для визначення рейтингу студентів при обчисленні та плануванні навчального навчання наукових i педагогічних працівників. Ця платформа активно використовується для організації електронного розкладу.

B BGKU (P5) використовуються електронні журнали та спеціальний модуль е-деканату на платформі LMS Moodle в системі електронного навчання, який інтегрований в есередовище університету.

PHDPU (P6) використовує електронну систему управління «1С: підприємство 8. Установка для вищих навчальних закладів України», яка дозволяє створювати єдине інформаційне середовище та забезпечити взаємодію всіх структурних підрозділів, зокрема, деканат.

B PTUSPU (P7) функціонує електронна платформа UA Бюджет.

B LTSNU (P9) частково використовується система електронного деканату (контингент, оцінка за семестрами).

\section{VI СИСТЕМА ОЦІНЮВАННЯ}

\section{Методика забезпечення якості оцінювання програм з використанням інноваційних методів та технологій навчання}

VSPNU (P1) розробляє систему оцінювання якості надання освітніх послуг, впровадження інноваційних методів навчання, розробляються методи вдосконалення та оцінювання робочих навчальних програм з різних дисциплін.

B BGKU (P5) розроблені нові шаблони для робочих навчальних та освітніх програм. Всі програми знаходяться в інституційному репозиторію. Програми додаються в нього тільки після перевірки, а потім вносяться до реєстрів.

PHDPU (P6) використовує методологію для забезпечення якості оцінювання програм, таких як: контроль, що проводиться під час відвідування навчальних занять представниками керівництва університету; взаємовідвідування навчальних занять викладачами; обговорення на засіданнях науково-методичної ради і Вченої ради діяльності кафедр, інших структурних підрозділів (управління дистанційного навчання, бібліотеки, управління інформаційних технологій тощо) щодо організації і науково-методичного забезпечення навчального процесу; отримання зворотного зв'язку від працедавців (через відгуки органів державного управління і місцевого самоврядування про результати стажування слухачів); отримання зворотного зв'язку від випускників університету (під час зустрічей 3 ними керівництва університету та анкетування).

В PTUSPU (P7) використовується контроль 3 боку адміністрації університету, факультетів/інституту; анкетування студентів щодо виявлення рівня якості надання освітніх 


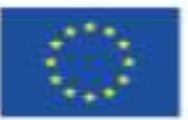

послуг з використання інноваційних методів та технологій навчання; взаємовідвідування занять викладачами кафедр факультету/інституту.

LTSNU (P9) існує стандарт забезпечення якості ЛНУ (2014).

\section{Оцінювання інноваційного змісту навчання та використання інноваційних методів та технологій навчання}

VSPNU (P1) забезпечує внутрішню систему забезпечення якості навчальних курсів. Після вивчення кожного курсу в кінці семестру організовується опитування студентів про ефективність окремих методів навчання, а також аналіз якості їх знань за результатами іспитів. У той же час після вивчення курсу представники університету проводять вибіркове анкетування студентів для оцінювання інноваційного змісту навчання на різних факультетах.

B BGKU (P5) опитування студентів «Оцінювання ЕНК» та «Викладач очима студента» проводиться щороку після завершення навчання з використанням ЕНК або за запитом щодо конкретного викладача.

В PHDPU (P6) студенти університету беруть активну участь у оцінюванні інноваційного змісту навчання, що проводиться за допомогою анкет, опитувань, оцінки інформації експертним методом. Студенти оцінюють зміст навчального плану та якість та ефективність навчання.

PTUSPU (P7) - 3 метою оцінки інноваційного змісту навчання та використання інноваційних методів та технологій навчання серед студентів проводиться анкетування, опитування та їх обговорення на засіданнях різних рівнів.

\section{Контроль та оцінка програм, що включають інноваційні методи та технології навчання}

B VSPNU (P1) оцінювання відбувається тільки за результатами навчальних досягнень студента, оцінюється якісна сторона впровадження інновацій.

В BGKU (P5) оцінювання програм здійснюється членами відповідних кафедр та експертною оцінкою відповідних фахівців та за допомогою анкетування студентів.

B PHDPU (P6) для оцінки програм застосовуються наступні методи: збір інформації спостереження, опитування, (усне опитування, інтерв'ю, інтерв'ю, письмове опитування, тестування, експеримент, контрольна робота), аналіз документів, контрольні заходи; накопичення та обробка інформації (статистичні методи, масштабування, рейтингова оцінка); оцінка інформації - експертний метод, аналіз результатів діяльності, статистичний аналіз; використання інформації - підготовка звітів, планування, корекція, попередження, прогнозування.

B PTUSPU (P7) проводиться внутрішній та зовнішній контроль за впровадженням в освітній процес методів та технологій навчання.

B LTSNU (Р9) проводиться експертна оцінка, зворотний зв'язок. 


\section{Рейтингова система для професорсько-викладацького складу}

B VSPNU (P1) здійснюється рейтингова оцінка роботи викладача за кожен календарний рік, що включає: участь у науково-дослідній діяльності, зокрема наукових грантових програмах (проєктах), отримання патентів, охоронних документів, авторських свідоцтв, ліцензій, активність щодо участі в наукових конференціях різних рівнів, друк наукової продукції (передусім у міжнародних виданнях, що входять до наукометричних баз даних), наукове керівництво (консультування) дисертаційних робіт здобувачів наукового ступеня, підготовку студентів для проходження по конкурсу i отримання гранту на навчання за програмою «Еразмус+» чи інших програм (в т.ч. переможців всеукраїнських олімпіад, конкурсів наукових робіт), участь у спеціалізованих вчених радах, робота у державних акредитаційних комісіях, експертних радах МОН України, науково-методичній комісіях, робочих групах МОН України та інших міністерств (за наказами), наукова співпраця із вітчизняними та/або закордонними науковими установами, наукові стажування чи інші форми підвищення кваліфікації тощо, а також кількість лекційних годин, кількість розроблених навчальних програм, курсів, наочно-презентаційного матеріалу, популяризацію інновацій у медіапросторі, створення і передача в електронну бібліотеку університету електронних ресурсів для внутрішнього користування (лекцій, посібників, наукових статей та ін.).

BGKU (P5) має рейтингову систему на основі е-портфоліо. Показники для оцінки діяльності академічного викладача:

1. Науково-дослідна діяльність

- Завершені наукові дослідження

- Участь у науково-дослідних проєктах та програмах

- Монографії

- Статті

- Індекс цитування відкритих публікації

- Науково-дослідні експедиції

- Професійний розвиток

- Захист дисертації

- Підвищення кваліфікації

- Реєстрація авторського права

- Перемога в спортивних змаганнях в якості спортсмена (команди) / тренера

- Презентація власних творів мистецтва на виставках

- Підготовка музичних, театральних, хореографічних проєктів (як режисерпостановник)

- Реалізація творчих проєктів

2. Викладацька діяльність

- Підручники, навчальні посібники, хрестоматії

- Енциклопедії

- Відеокурс

- Використання ЕНК студентами 
- Рейтинг викладача за анкетуванням студентів

- Підготовка переможця етапу Всеукраїнської студентської олімпіади, конкурсу студентських наукових робіт, наукового конкурсу, турніру, проєкту

PHDPU (P6) проводить щорічну оцінку професійної діяльності наукових та педагогічних працівників на трьох позиціях:

• показники професійного розвитку включають 6 критеріїв;

• показники освітньої діяльності включають 12 критеріїв;

• показники наукової та інноваційної діяльності включають 17 критеріїв.

В PTUSPU (P7) щорічно здійснюється визначення рейтингу професорськовикладацького складу за такими показниками діяльності: наукова, навчально-методична та організаційно-виховна діяльність.

B SUNPUU (P8) снує університетська система оцінювання викладачів, яка враховує всі напрямки діяльності викладача (наукові, методичні та організаційні). Оцінка всіх викладачів на кінець кожного року визначається на основі цієї системи.

LTSNU (P9) існує науковий рейтинг (кількість публікацій, h-індекс).

\section{VII НАВЧАЛЬНА КУЛЬТУРА}

\section{Стимулювання та підтримка співробітників у використанні електронного навчання та інноваційних методів навчання}

B VSPNU (P1) впроваджено додаткове фінансування, заохочення ректора, додаткові бали в процесі професійної оцінки академічних інструкторів, презентація кращого досвіду, залучення до роботи у міжнародних проєктах, фінансова підтримка участі в наукових конференціях, друк монографій для майбутніх здобувачів наукового ступеня доктора наук тощо.

B BGKU (P5) запроваджено конкурс «Лідер року». Переможці обираються на підставі результатів рейтингу е-портфоліо, який включає в себе наступні показники: науководослідну діяльність, професійний розвиток та викладацьку діяльність (зокрема, розробка та використання електронних курсів). Переможці конкурсу отримують грошові винагороди.

B PHDPU (P6) річна рейтингова оцінка науково-педагогічних працівників включає такі посади:

- розробка та розміщення на сайті навчально-методичних комплексів 3 предмету, методичних електронних освітніх ресурсів (20 балів за курс);

- розробка та використання відеолекцій та мультимедійних презентацій лекційних курсів (10 балів за кожну лекцію);

- розміщення наукових розробок у репозиторії університету (від 10 до 30 балів залежно від характеру і обсягу розробки).В PTUSPU (P7) використовуються додаткові бали в рейтингу.

B PTUSPU (P7) здійснюється завдяки нарахуванню додаткових балів у рейтингу викладача. 


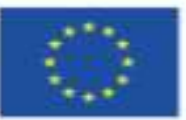

B SUNPUU (P8) нараховуються додаткові бали до рейтингу викладача, винагороди ректора, презентація кращого досвіду.

В LTSNU (Р9) використання методів електронного навчання є обов'язковим для всіх.

\section{Оцінювання цифрових компетентностей викладачів}

B BGKU (P5) за допомогою інструментів відкритого оцінювання, зазначених у моделі IC Competency, проводиться перевірка рівня IК-компетентності після закінчення підвищення кваліфікації із зазначеного модуля, самооцінювання, взаємооцінювання, порівняння 3 вимогами цифрового стандарту викладачів, система показників для їх оцінювання.

B PHDPU (P6) - цифрові навички та педагогічна компетенція вчителів щодо інноваційних програм оцінюються за допомогою відкритих інструментів оцінки, зазначених у моделі IC Competency:

1. Інформаційна грамотність та грамотність щодо роботи з даними.

1.1. Уміння шукати, фільтрувати дані, інформацію та цифровий контент.

1.2. Уміння оцінювати дані, інформацію та цифровий контент.

1.3. Уміння використовувати та управляти даними, інформацією та цифровим контентом.

2. Комунікація та взаємодія.

2.1. Уміння спілкуватися через використання цифрових технологій.

2.2. Уміння ділитися інформацією завдяки використанню цифрових технологій.

2.4. Уміння взаємодіяти завдяки використанню цифрових технологій.

2.5. Знання «нетикету» (від англ. network та etiquette), тобто володіння правилами поведінки та етикету в цифровому середовищу.

2.6. Управління цифровою ідентичністю, тобто вміння створювати та управляти акаунтами.

3. Цифровий контент.

3.1. Створення цифрового контенту.

3.2. Уміння змінювати, покращувати, використовувати цифровий контент задля створення нового контенту.

3.3. Обізнаність щодо авторських прав та політики ліцензування відповідно до даних, інформації та цифрового контенту.

3.4. Програмування, тобто вміння писати програмний код.

4. Безпека.

4.1. Уміння захистити пристрої та контент, знання заходів безпеки, розуміння ризиків та загроз.

4.2. Захист персональних даних та приватності.

4.3. Охорона здоров'я, тобто знання та навички для збереження свого здоров'я та інших 3 точки зору як екології використання цифрових технологій, так і ризиків, загроз безпеці громадян. 


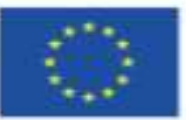

4.4. Захист навколишнього середовища, тобто розуміння впливу цифрових технологій на екологію, навколишнє середовище, з точки зору їх утилізації, а також їх використання, що може нанести шкоду, наприклад, об’єктам критичної інфраструктури.

5. Вирішення проблем.

5.1. Уміння вирішувати технічні проблеми, що виникають із комп’ютерною технікою, програмним забезпеченням, мережами тощо.

5.2. Уміння визначати потреби та знаходити відповідні технічні рішення, або кастимізувати цифрові технології до власних потреб.

5.3. Креативне користування, або вміння завдяки цифровим технологіям створювати знання, процеси та продукти, індивідуально або колективно, 3 метою вирішення повсякденних життєвих та професійних проблем.

5.4. Уміння самостійно визначати потребу в отриманні додаткових нових цифрових навичок.

B PTUSPU (P7) оцінювання цифрових компетентностей не передбачено.

B LTSNU (P9) цифрові навички академічних інструкторів не оцінюються.

\section{Оцінювання цифрових компетентностей студентів}

У VSPNU (P1) визначення рівня розвитку цифрової компетентності студентів здійснюється здебільшого в контексті вивчення курсів 3 інформаційних технологій та комунікаційних технологій (приміром, факультет інформатики та математики). На окремих кафедрах університету (наприклад, кафедра педагогіки початкової освіти, кафедри менеджменту та ділового адміністрування, фахових методик і технологій початкової освіти та інших) студенти проходять тестування за конкретними темами або розділами навчального курсу за допомогою дистанційної форми навчання на платформі університету (http://www.dlearn.pu.if.ua/). Це необхідно, щоб отримати доступ для здачі іспиту. Студенти також мають можливість дистанційної здачі заліків (екзаменів) за погодженням 3 викладачем. На платформі EduPRO для електронного навчання (e-Learning) для студентів завантажено навчальні ресурси з усіх дисциплін, що вивчаються в університеті, у т.ч. завдання для підсумкового контролю. Для роботи з сайтом рекомендовано використовувати один із браузерів - Mozilla Firefox, Google Chrome чи Opera.

Викладачами VSPNU (P1) також ведеться значна робота щодо захисту студентів від недосконалого цифрового контенту, що може зашкодити фізичному, психічному чи соціальному здоров'ю та розвитку, відсутності механізмів ефективної саморегуляції інформаційного ринку, щоб не допустити соціально шкідливих інформаційних впливів тощо.

B BGKU (P5) перевіряється рівень формування студентської цифрової компетентності шляхом проходження ними спеціально розробленого тесту в системі е-навчання LMS Moodle.

B PHDPU (P6) формування відповідного рівня цифрової компетентності у студентів підтверджується шляхом проходження спеціально розробленого тесту Moodle. Оцінюються такі цифрові навички та компетентність студентів: інформаційна та цифрова компетенція, 
яка забезпечує впевненість i в той же час критичне застосування інформаційнокомунікаційних технологій для створення, пошуку, обробки, обміну інформацією на роботі, у громадському просторі та в приватних умовах. спілкування; майстерність інформаційної та медіа грамотності, основи програмування, формування алгоритмічного мислення, вміння працювати з базами даних, навички роботи в Інтернеті та кібербезпека; розуміння етики роботи з інформацією (авторське право, інтелектуальна власність тощо).

PTUSPU (P7) лише в контексті навчання викладачами інформатичних дисциплін.

SUNPUU (P8) - оцінювання цифрових компетентностей здійснюється.

В LTSNU (Р9) цифрові навички студента вимірюються та оцінюються в курсі «Пропедевтика та ІКТ».

\section{Вирішення завдань персоналізації та адаптивного навчання}

B VSPNU (P1) використовується мобільне навчання (факультет природничих наук та факультет інформаційних технологій), персональні комп'ютери в комп'ютерних класахлабораторіях (переважно в навчанні дисциплін з IКТ). Відкриті інтернет-ресурси, Youtube, цифрові бібліотеки, Google, Moodle, Google Classroom тощо.

B BGKU (P5) персоналізація, адаптивне навчання рекомендовані та використовуються для навчання в переважній більшості дисциплін. Студенти мають власні корпоративні акаунти в поштових службах, доступ до хмарних сервісів, де вони можуть організувати власне персоналізоване навчальне середовище та розмістити е-портфоліо. LMS Moodle дозволяє студенту планувати власну освітню діяльність та адаптувати освітній процес до власних потреб. Університет використовує технологію чат-ботів, які дозволяють швидко отримати інформацію про організацію освітнього процесу. Адаптивна система навчання, що передбачає різний спосіб подання теоретичного матеріалу, визначення кінцевих термінів виконання завдань та надсилання відповідних завітів, тощо, враховує потреби студента, його фізіологічні особливості та стиль навчання.

B PHDPU (Р6) відбувається проведення презентацій, вимірювань, спостережень, експериментів, розробки проєктів, обговорення, обговорення, тестування, створення ідей, асиміляція навчальних стратегій за допомогою мультимедіа. Платформа 3 адаптивним контентом - Moodle, безкоштовний ресурс з освітніми програмами, лекції, тести, завдання для самостійної роботи.

В PTUSPU (P7) вирішення проблеми персоналізації та адаптивного навчання здійснюється завдяки використанню технологій мобільного навчання та хмарних технологій.

SUNPUU (P8)- так, персональний комп'ютер, гаджети та планшети, окремі завдання.

В LTSNU (Р9) індивідуалізація здійснюється за рахунок вибору тьютором персональних рекомендацій для студента. 


\section{ВИСНОВКИ}

До проєкту долучено університети з приблизною кількістю студентів від 4,5 тис до майже 15 тис. Чисельно викладацький склад різниться від 374 викладачів до 1350 (Мал. 2).

Університети - партнери проєкту структуровані переважно за інститутами та факультетами (таблиця 1).

Дане дослідження дає змогу стверджувати, що інноваційне викладання актуальне в кожному з університетів. Університети - партнери проєкту, долучаються до наукової проєктної діяльності, маючи у своєму активі й міжнародні проєкти (таблиця 2).

Усі університети дотримуються правових документів прийнятих на державному рівні та активно розбудовують свою нормативну базу (таблиця 3), яка включає Положення про організацію освітнього процесу, рейтингове оцінювання діяльності викладачів та студентів, систему заохочення тощо.

Дистанційне навчання та використання відкритих освітніх ресурсів документально затверджене лише в BGKU (P5), в інших використовується лише як додаткові форми навчання.

Університети запровадили системи контролю якості навчальних матеріалів, здійснюючи кафедральну та зовнішню експертизи, та контролюють рівень задоволення студентів, проводячи опитування та анкетування студентів.

В усіх українських університетах - партнерах проєкту $є$ спеціальні підрозділи підтримки інноваційних методів та технологій навчання, що координують та підтримують впровадження інноваційних інструментів та технологій навчання.

Кожен університет в своїх робочих програмах пропонує опис результатів навчання, зазначаючи переліки компетентностей та критерії оцінювання їхньої сформованості.

Приклади практичних та наукових досліджень студентів в університетах оприлюднюються на порталах, збірках наукових праць, доповідях на конференціях тощо. Завдяки своїй науковій дослідницькій діяльності студенти університетів посідають призові місця на студентських олімпіадах та різноманітних змаганнях.

Найбільш використовуваними інноваційними методами та технологіями навчання університети - українські партнери проєкту, зазначили такі (Таблиця 4):

- Змішане навчання/Hybrid (5)

- Проєктна діяльність (3)

- Групова та парна навчальна діяльність (3)

- Електронне навчання (3)

- Навчання на основі досліджень (3) 


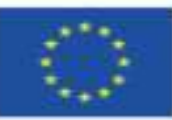

Таблиця 4.

\begin{tabular}{|c|c|c|c|c|c|c|c|c|c|c|c|c|c|c|}
\hline & 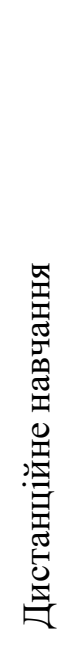 & 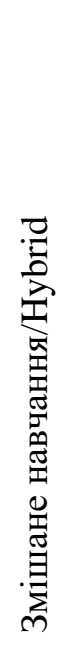 & 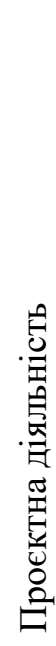 & 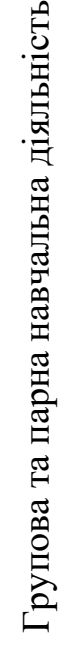 & 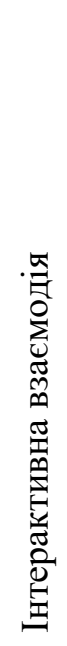 & 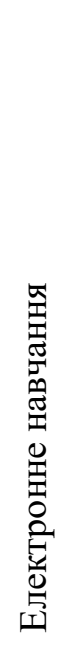 & 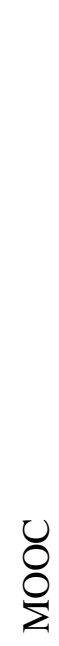 & 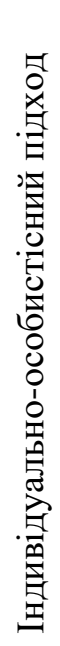 & 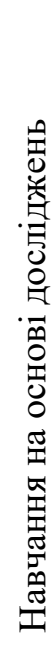 & 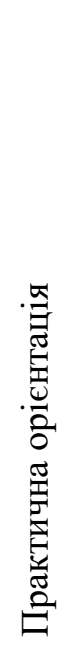 & 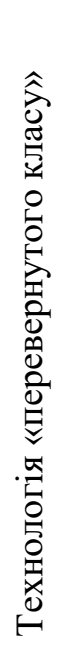 & 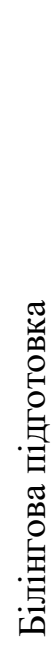 & 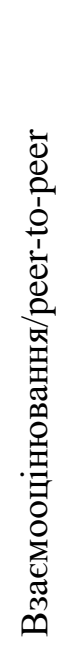 & $\underset{\mathrm{I}}{\mathrm{I}}$ \\
\hline VSPNU (P1) & + & + & + & + & + & + & & & & & & & & \\
\hline BGKU (P5) & + & + & + & + & & & + & + & + & + & + & + & + & \\
\hline PHDPU (P6) & & + & & + & & + & & & + & + & + & + & & + \\
\hline PTUSPU (P7) & & + & & & & + & & & & & & & & \\
\hline SUNPUU (P8) & & + & & & & & & & & & & & & \\
\hline LTSNU (P9) & & & + & & & & & & + & & & & & \\
\hline
\end{tabular}

Проведений в рамках виконання завдань проєкту аналіз досвіду використання кращих педагогічних практик, врахування їх у освітніх програмах, демонструє нагальну потребу у активізації введення освітніх трендів до програмних та нормативних документів університетів задля підвищення якості надання вищої освіти.

Оцінка рівня адміністративної підтримки інноваційної діяльності викладачів свідчить, що керівництво закладів вищої освіти може створювати сприятливі умови для ширшого використання викладачами інноваційних методів та технологій навчання, надання студентам можливості набуття навичок користування цифрових інструментів, та використання їх для ефективної роботи в Інтернеті, створення електронного контенту, участі у науковій, проєктній та дослідницькій діяльності тощо. 


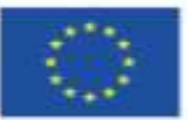

\section{СПИСОК ВИКОРИСТАНИХ ДЖЕРЕЛ}

1. European Commission. Communication from the commission to the european parliament, the council, the european economic and social committee and the committee of the regions. An Agenda for new skills and jobs: A European contribution towards full employment. November 15, 2018. URL: http://eur-lex.europa.eu/resource.html?uri=cellar:776df18f-542f-48b8-962788aac6d3ede0.0003.03/DOC_1\&format=PDF

2. European Commission. Communication from the commission to the european parliament, the council, the european economic and social committee and the committee of the regions a digital single market strategy for Europe. November 15, 2018. URL: http://eur-lex.europa.eu/legalcontent/EN/TXT/PDF/?uri=CELEX:52015DC0192\&from=EN

3. Kampylis, P., Punie, Y., Devine, J. Promoting Effective Digital-Age Learning - A European Framework for Digitally-Competent Educational Organisations; EUR 27599 EN. 2015. doi:10.2791/54070

4. Official EU Site. Europe 2020. November 15, 2018. URL: https://ec.europa.eu/info/businesseconomy-euro/economic-and-fiscal-policy-coordination/eu-economic-governance-monitoringprevention-correction/european-semester_en

5. Union, I. Communication from the Commission to the European Parliament, the Council, the European Economic and Social Committee and the Committee of the Regions. A new skills agenda for europe. Brussels. 2014

6. Vuorikari, R., Punie, Y., Carretero Gomez S., Van den Brande, G. DigComp 2.0: The Digital Competence Framework for Citizens. Update Phase 1: The Conceptual Reference Model. Luxembourg Publication Office of the European Union. EUR 27948 EN. 2016. doi:10.2791/11517

7. Гриневич Л., Елькін О., Калашнікова С., Коберник І., Ковтунець В. та ін.. Нова Концепція української школи. За заг. ред. М. Грищенко URL: https://www.kmu.gov.ua/storage/app/media/reforms/ukrainska-shkola-compressed.pdf

8. Морзе Н.В, Василенко С.В., Гладун М.А. Шляхи підвищення мотивації викладачів університетів до розвитку їх цифрової компетентності Збірка наукових праць «Відкрите освітнє е-середовище сучасного університету», № 5 (2018) URL: http://openedu.kubg.edu.ua/journal/index.php/openedu/article/view/164\#.XDS1HlwzY2w

9. Розпорядження Кабінету міністрів України. Про схвалення Концепції розвитку цифрової економіки та суспільства України на 2018-2020 роки та затвердження плану заходів щодо iii реалізації» від 17 січня 2018 р. № 67-p. URL: http://zakon3.rada.gov.ua/laws/show/67-2018$\mathrm{p}$ 


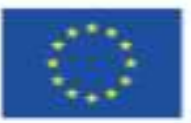

\section{Додаток 1. Опитувальник «Вхідне опитування університетів MoPED про контингент»}

\section{Вхідне опитування університетів проекту MOPED про контингент}

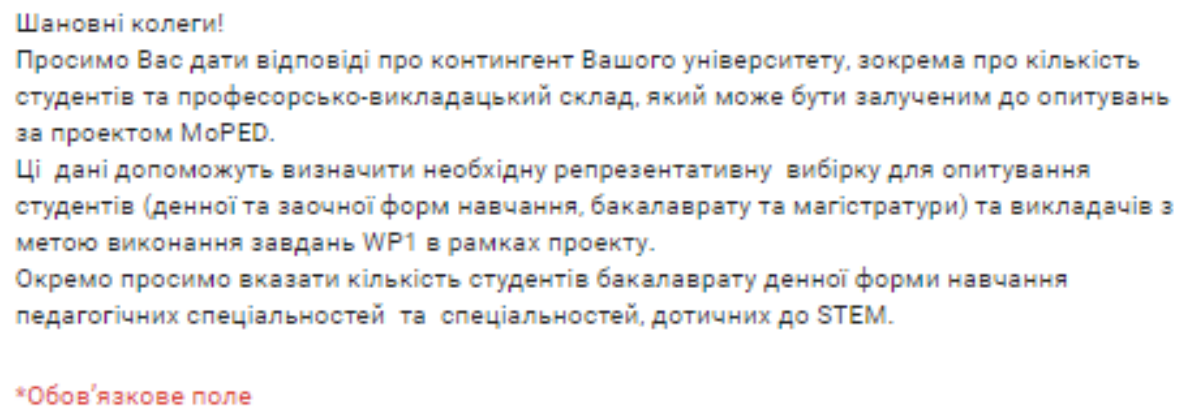

Електронна адреса *

Ваша електронна адреса

\section{Оберіть Ваш університет *}

ДВНЗ Прикарпатський національний університет ім. В. Стефаника

Київський університет імені Бориса Грінченка

О) Переяслав-Хмельницький державний педагогічний університет ім. Григорія Сковороди

Уманський державний педагогічний університет ім. Павла Тичини

Південноукраїнський національний педагогічний університет ім. К.Д. Ушинського

Луганський національний університет ім. Тараса Шевченка 
Вкажіть кількість студентів бакалаврату денної форми, які навчаються у Вашому університеті *

Ваша відповідь

Вкажіть кількість студентів магістратури денної форми, які навчаються у Вашому університеті *

Вөша відповідь

Вкажіть кількість студентів бакалаврату заочної форми, які навчаються у Вашому університеті *

Ваша відповідь

Вкажіть кількість студентів магістратури заочної форми, які навчаються у Вашому університеті *

Ваша відповідь

Вкажіть кількість штатних викладачів *

Ваша відповідь

Запишіть напрями підготовки студентів, що мають педагогічну складову *

Ваша відповідь

Вкажіть кількість студентів денної форми бакалаврату, які навчаються на зазначених напрямах підготовки із педагогічною складовою * 
Вкажіть кількість штатних викладачів, які навчають студентів на напрямах підготовки з педагогічною складовою *

\section{Ваша відповідь}

Зазначте напрями підготовки студентів Вашого університету, дотичні до STEM *

\section{Ваша відповідь}

Вкажіть кількість студентів денної форми бакалаврату, які навчаються на зазначених напрямах підготовки, дотичних до STEM *

\section{Ваша відповідь}

Вкажіть кількість штатних викладачів, які навчають студентів на напрямах підготовки, дотичних до STEM *

\section{Ваша відповідь}

\section{Надіслати мені копію моїх відповідей.}

\section{НАДІСЛАТИ}

Ніколи не вказуйте паролі в Google Формах. 


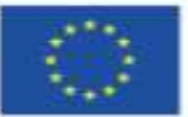

\section{Додаток 2. Шаблон опитувальника для дослідження ресурсів, інноваційного навчання та кращих практик у застосуванні сучасних інструментів IKT}

MoPED Modernization of Pedagogical Higher Education by Innovative Teaching Instruments

No. 586098-EPP-1-2017-1-UA-EPPKA2-CBHE-JP

Erasmus+KA2 CBHE

Template: Partner/Courses

PART A Information about innovative teaching and technology instruments utilized in the University Note: each Partner should fill in Part A once only

Name of provider:

Short description of the University:

number of students -

number of faculties

number of academic instructors

\section{A.I GENERAL ADMINISTRATIVE INFORMATION ABOUT THE UNIVERSITY}

A.I.1 What projects referring to innovative teaching and/or application of technologies in teaching/learning have been launched in the University?

A.I.2 What ICT infrastructure is used at the University to support digital learning?

Name as much tools and applications used as possible and write which initiatives do they support e.g. creating online and blended courses, individual courses, MOOCs, online Bachelor and Master programmes, continuing program development etc.

\section{A.II ORGANIZATIONAL LEVEL}

A.Il.1 Are innovative teaching and technology instruments mentioned in the strategic documents of your university (eg. mission, strategy, development plan etc.)? 
ISSN: 2414-0325. Open educational e-environment of modern University, special edition (2020)

Please consider innovative teaching and technology instruments for academic instructors and students. Please describe in few sentences how innovative teaching and technology instruments are introduced in the Development Strategy.

A.Il.2 What is the legal framework for innovative teaching and technology instruments in your country and in your university?

A.Il.3 Legal perspective - Are academic instructors allowed to replace a certain number of traditional inclass hour with online hours or online learning is considered only as an additional activity to traditional inclass hours?

A.Il.4 Does the university recognize the certificates received by students after completing external online courses (e.g. MOOCs)?

A.Il.5 Is there at the university a quality control system for monitoring the quality of training course materials, the level of students' satisfaction with the prepared materials? If yes, what statistics are measured?

Please, provide examples.

A.Il.6 Is there a special support unit in the university for innovative teaching and technology instruments? What kind of support does it offer?

eg. Virtual Learning Environment, training and consultancy in technology and pedagogy, support in teaching

A.Il.7 How many programmes are supported by innovative teaching and technology instruments? What type of courses are supported? 
ISSN: 2414-0325. Open educational e-environment of modern University, special edition (2020)

A.II.8 Intellectual property support - Is there a university/department unit which provides support in intellectual property rights for academic instructors?

Is there eg IPR policy at university level.

Are academic instructors familiar with educational fair use? Do they know how to use material for

educational purposes?

A.Il.9 Is there a specialized unit at the university that is responsible for the implementation of innovative teaching and technology instruments and assessment of their outcomes?

eg. author of the course (an academic instructor), dean, rector, the council of the faculty

A.II.10 Is there a university repository of educational resources that can be used for courses delivered by the university?

Short description of the repository structure

\section{A.III SYLLABUS LEVEL AND TEACHING PRACTICE}

A.III.1 Are learning outcomes defined and described for each course?

Are learning outcomes defined for each lecture and classes (and an academic instructor really refers to them) or only for the course (they are formulated in the syllabus but not applied in practice)?

How are the competencies and indicators of their measurement described?

A.III.2 Does the University pay attention to using real-life case studies and scientific research results, so that it would be easier for students to prepare their tasks meaningfully?

If yes, please describe the forms.

A.III.3 Are any forms of innovative teaching and technology instruments defined in syllabi?

e.g. Mobile Learning 
ISSN: 2414-0325. Open educational e-environment of modern University, special edition (2020)

A.III.4 How does the University support Departments or Faculties in reviewing and re-designing their curricula?

A.III.5 What is the syllabus structure and how does the structure support multidisciplinary and flexibility of a course?

e.g. of syllabus structure: modular structure

A.III.6 Are there at the university courses or learning modules integrated in the curriculum, during which cover the subject of "Distance Education Technologies" is discussed?

A.III.7 Are Open Educational Resources utilized in courses? How?

A.III.8 Are any resources from the course published as Open Educational Resources under Creative Commons license?

If yes, please provide examples.

A.III.9 Are curricula designed in a way enabling online or face-to-face inter-institutional collaboration?

Is peer to peer evaluation used?

What methods and tools are used for peer-to-peer evaluation?

Please, provide examples. 
ISSN: 2414-0325. Open educational e-environment of modern University, special edition (2020)

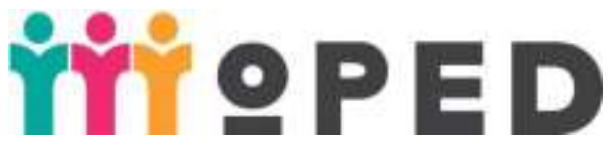

Co-funded by the Erasmus+ Programme of the European Union

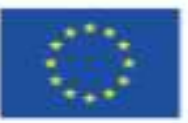

A.III.10 Is there a training course for teaching integrated education (in elementary school, secondary school, and profile school)?

A.III.11 Is there a concept for teaching students soft skills? How is the formation of soft skills in students assessed? Is there a special course for this?

A.III.12 Is there a special methodology for teaching students critical thinking? What methods, technologies and ICT tools are used for this?

\section{A.IV COMMUNITY LEVEL}

A.IV.1 Active Learning Communities - Do students participate actively in shaping their learning environment? How are students' opinions reviewed?

A.IV.2 Is there any exchange of the good practices among academics on the faculty and university level? If yes, how is it organised?

If yes, please, provide examples how is it organized.

E.g. seminars, workshops, periodic assessments.

A.IV.3 Diversity - How do academic instructors diverse their educational experience with different cultural background (such as ERASMUS+ programme)?

A.IV.4 Engagement in research - How the process of engaging students into scientific research projects is organised? 
ISSN: 2414-0325. Open educational e-environment of modern University, special edition (2020)

Is the project training system used?

How are ideas defined for projects?

Starting with which course is the project method implemented?

How is project design evaluated?

\section{A.V TECHNOLOGICAL LEVEL}

A.V.1 What kind of innovative teaching and technology instruments are implemented?

Is there Learning Management System (LMS) provided for the whole uni? What other tools are used? Provide a short description and name of the tools e.g. for webinars, plagiarism, video-streaming, virtual labs Does the University have an automated university management system? What statistical data can be systematically obtained on the basis of the use of the automated management system of the University?

A.V.2 How does the university's administration support introducing and using e-learning infrastructure?

A.V.3 How does digital infrastructure support custom teaching activities (multi-side classrooms)?

A.V.4 How is online environment used to support courses?

\section{Example:}

Online environment <of the type ...., based on software ... > :

helps to deal with organizational aspects of the course

provides learning resources

organizes activities and active online learning

A.V.5 What are the main investments in digital infrastructure in last several years?

e.g. Wi-Fi for students and academic instructors free of charge, projectors, free IT labs, cameras, laptops in lecture classes

A.V.6 Are communication systems secure, reliable? Do they assure appropriate levels of privacy? 
ISSN: 2414-0325. Open educational e-environment of modern University, special edition (2020)

As measures we can use the time for system recovery after a failure or a breakdown.

A.V.7 Is there a start-up at the Universities, does the eco-system of the University develop?

A.V.8 Give examples of the transformation in the educational process of the university, which occurred due to the effective introduction of ICT.

A.V.9 Is the e-portfolio of the student, e-portfolio of the academic instructors being introduced at the University? What technologies are used for this?

A.V.10 Do academic instructors have their own electronic office? What components does it contain? Based on what tools the academic instructor's electronic office was created?

A.V.11 Are there electronic journals in the learning process? What technologies and tools are used for the electronic register of grades?

A.V.12 Does the University use the electronic dean's system? 
A.VI EVALUATION LEVEL

A.VI.1 Evaluation of innovation - Has the University implemented methods for assuring the quality of evaluation of programmes involving innovative teaching and technology instruments?

A.VI.2 How are students being engaged in evaluating innovative teaching content? What methods of assessment are used by students to evaluate programmes containing innovative teaching and technology instruments?

A.VI.3 What methods are used to evaluate programmes involving innovative teaching and technology instruments?

A.VI.4 What methods and tools are utilized in the University for assessing programmes containing innovative teaching and technology instruments?

A.VI.5 Does the University have a rating system for academic instructors? Which indicators for assessing the activities of the academic instructor are used?

\section{A.VII EDUCATIONAL CULTURE}

A.VII.1 What incentives are used at the University to support academic staff in developing e-learning and innovative teaching methods?

e.g. additional funding, Rector's awards, additional points in academic instructors professional evaluation process, grants for programmes, other types of recognition, best practice presentation etc.

A.VII.2 Are digital skills and teaching competency of academic instructors towards innovative programmes evaluated and assessed? 
ISSN: 2414-0325. Open educational e-environment of modern University, special edition (2020)
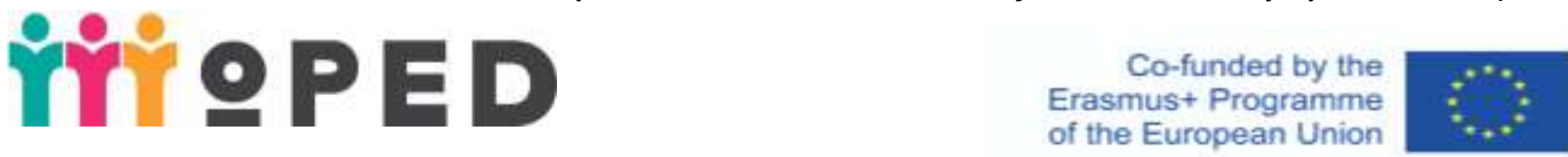

A.VII.3 Are digital skills and competency of students evaluated and assessed?

A.VII.4 Is personalization, adaptive learning used in learning? Please describe the tools for personalization. What ICT tools are used for this? 
ISSN: 2414-0325. Open educational e-environment of modern University, special edition (2020)

\section{ทั丷 PED}

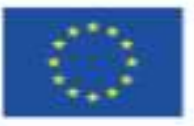

PART B Examples on the best practices in introducing innovations

Examples of courses/modules which:

- use interactive teaching environment

- build active learning experience

\section{B.I GENERAL INFORMATION ABOUT THE COURSE/MODULE}

B.I.1 Title of the course

\section{B.I.2 Department}

\section{B.I.3 Lecturer}

optional: email contact

\section{B.I.4 Type of science}

e.g. Engineering, Natural, etc.

B.I.5 Type/Class format/Program structure

number of lectures, practical classes, other work, obligatory or selective, etc.

B.I.6 Case reference: module /type of the course/course/method

B.I.7 Link to the syllabus 
B.I.8 Number of ECTS assigned to the course or module:

B.I.9 Level of studies

e.g. Bachelor studies, Master studies, Post-Graduate studies, Doctoral studies

\section{B.II SHORT DESCRIPTION OF THE COURSE}

B.Il.1 Prerequisites

B.II.2 Course description

B.II.3 Educational methods

B.II.4 Learning outcomes

B.II.5 Assignment evaluation/Grading basis/Form of control

\section{B.III COURSE DESIGN}


ISSN: 2414-0325. Open educational e-environment of modern University, special edition (2020)

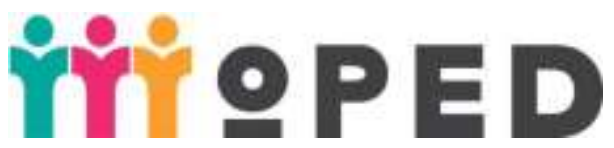

Co-funded by the Erasmus+ Programme of the European Union

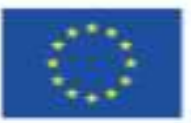

B.III.1 How is the course organised and implemented?

Eg. online, blended, etc.

Provide a description.

B.III.2 What kind of innovative activities are performed by the students and how are they aligned with achieving learning outcomes?

Examples:

- sending an assignment to be assessed

- reading resources

- taking an online test

- online discussion

- peer-assessment

- attending webinars

- collaboration with peers on the project

B.III.3 How do e-learning materials help students to commit actively to the course? How do e-learning enable students to test their knowledge, abilities and skills?

B.III.4 Are Open Educational Resources used in the course?

If yes, please provide examples.

B.III.5 How is coherence achieved between learning outcomes, the strategy of using of e-learning, the scope of the learning materials and the assessment methods used?

B.III.6 What kind of assessment is implemented for the learning outcomes designed for the course? 


\section{B.IV INNOVATIVE APPROACH - CASE STUDY}

B.IV.1 What have convinced you to adopt such approach to this course?

B.IV.2 What is your approach based on? How do you use e-learning and active learning methods?

B.IV.3 What have inspired you for designing your course this way?

B.IV.4 How has the new approach improved the initial form of the course?

B.IV.5 What are tangible key performance measures for your approach?

B.IV.6 How do the student benefit from the new approach?

B.IV.7 What are strengths and weaknesses of your approach? 